University of Louisville

ThinkIR: The University of Louisville's Institutional Repository

Electronic Theses and Dissertations

$5-2014$

\title{
Legislation and its effects on race relations in southeastern Indiana, 1785-1860.
}

D. W. Varble

University of Louisville

Follow this and additional works at: https://ir.library.louisville.edu/etd

Part of the History Commons

\section{Recommended Citation}

Varble, D. W., "Legislation and its effects on race relations in southeastern Indiana, 1785-1860." (2014). Electronic Theses and Dissertations. Paper 1485.

https://doi.org/10.18297/etd/1485

This Master's Thesis is brought to you for free and open access by ThinkIR: The University of Louisville's Institutional Repository. It has been accepted for inclusion in Electronic Theses and Dissertations by an authorized administrator of ThinkIR: The University of Louisville's Institutional Repository. This title appears here courtesy of the author, who has retained all other copyrights. For more information, please contact thinkir@louisville.edu. 
LEGISLATION AND ITS EFFECTS ON RACE RELATIONS IN SOUTHEASTERN

INDIANA, 1785-1860

D. W. Varble

\author{
A Thesis \\ Submitted to the Faculty of the \\ College of Arts and Sciences of the University of Louisville \\ In Partial Fulfillment of the Requirements \\ For the Degree of \\ Master of Arts \\ Department of History \\ University of Louisville \\ Louisville, Kentucky
}

May 2014 

LEGISLATION AND ITS EFFECTS ON RACE RELATIONS IN SOUTHEASTERN

INDIANA, 1785-1860

D. W. Varble

B. A., Indiana University, 1990

A Thesis Approved on

April 2, 2014

By the following Thesis Committee:

Dr. Thomas Mackey, Thesis Director

Dr. Dewey Clayton

Dr. Benjamin Harrison 


\section{ACKNOWLEDGEMENTS}

I must thank Dr. Thomas Mackey for his support and suggestions. I would also like to thank Dr. Benjamin Harrison and Dr. Dewey Clayton for serving on my committee. I also need to thank my family for their patience during this process. Finally, I appreciate the assistance provided by the staffs of all the libraries I visited, especially Hanover College Duggan Library, Madison-Jefferson County Public Library, University of Louisville Ekstrom Library, and New Albany-Floyd County Public Library. 


\section{ABSTRACT \\ LEGISLATION AND ITS EFFECTS ON RACE RELATIONS IN SOUTHEASTERN INDIANA, 1785-1860 \\ D. W. Varble}

April 2, 2014

Residents of Indiana debated the status of Blacks from the time the area was part of the Northwest Territory until the Civil War. An anti-slavery faction gained control of the Indiana territorial legislature and assured Black's rights through early statehood; however, from the mid-1820s until 1851 anti-black leaders passed repressive legislation. Officials in the southeastern Indiana counties and cities ignored the repressive laws unless events forced them to act. In 1820 one in four Blacks in Indiana lived in the southeastern counties of Jefferson, Clark, and Floyd. By 1850, those county's seats Madison, Jeffersonville, and New Albany, respectively - were the largest urban areas in Indiana. Businesses of those counties and cities relied on trade with the slave state of Kentucky, but also relied on the industry of their Black residents. For these two reasons, those counties and cities developed distinctively from the rest of the state. 


\section{TABLE OF CONTENTS}

ACKNOWLEDGEMENTS

ABSTRACT iv

CHAPTER 1 Protection of Rights, 1785-1824 1

CHAPTER 2 Repression, 1824-1850 29

CHAPTER 3 Slave Catchers and Exclusion, 1850-1860 47

$\begin{array}{llr}\text { CHAPTER } 4 \text { Historiography } & 83\end{array}$

$\begin{array}{ll}\text { REFERENCES } & 103\end{array}$

$\begin{array}{ll}\text { CURRICULUM VITA } & 109\end{array}$ 


\section{CHAPTER 1}

PROTECTION OF RIGHTS, 1785-1824

In 1787, the Congress of the Articles of Confederation adopted the Northwest Ordinance for the governance of the vast territory north and west of the Ohio River. Later in 1787, the same Congress called for a convention to revise the Articles of Confederation, which united the states. However, instead of a revision the convention replaced the Articles with a new central government under the 1787 Constitution of the United States. The provisions in regard to slavery in both the Northwest Ordinance and the Constitution of the United States played an important role in the development of the territory, and later state, of Indiana.

The Northwest Ordinance provided a governor, a secretary, and three judges to govern the people of the Northwest Territory. The Congress of the Confederation appointed each official until the Constitution replaced the Congress. In the new government under the Constitution, the President of the United States appointed, with Senate approval, the officials to the Northwest Territory. The Ordinance included a provision for representative government when the population of the territory reached 5000. The Congress of the Confederation created one of the earliest written bills of rights in the Ordinance. ${ }^{1}$ Among the list of rights, Article VI of the Ordinance stated, "There

1 John D. Barnhart and Dorothy L. Riker, Indiana to 1816: The Colonial Period (Indianapolis: Indiana Historical Society, 1971), 267-269. 
shall be neither Slavery nor involuntary Servitude in the said territory otherwise in punishment of crimes." ${ }^{2}$ However, debates over the existence of slavery continued. Between the creation of the Northwest Territory and the time Indiana became a state in 1816 , territorial legislation permitted a form of slavery in the territory, but anti-slavery advocates fought to repeal this measure. After Indiana became a state in 1816, the debates centered on the rights of Blacks who lived in the area and those debates lasted for the next forty-five years. Chapter one of this thesis examines the controversy over the introduction of slavery during Indiana's territorial period and reviews the efforts of state officials to assure the legal protection of Blacks and their property. Chapter one argues that although pro-slavery proponents gained control of Indiana politics during the early stages of development, the anti-slavery advocates soon took control and Blacks felt safe in Indiana. Chapter two discusses the state legislature's shift away from Black rights and the struggles of those who continued to aid Blacks. This thesis concludes with an analysis in Chapter 3 of 1850s national legislation in regards to Blacks and the effects that legislation had on Indiana residents. The entire thesis pays particular attention to the events in southeastern Indiana, specifically Floyd, Clark, and Jefferson counties, and compares the events when possible to Ohio and Illinois, two other states created out of the Northwest Territory. In 1850 Madison, in Jefferson County, was the largest city in the state with a population of over 9000. New Albany, in Floyd County, was the second largest city with a population of over 8000 and Jeffersonville, in Clark County, had over 2500 residents. The combined population of New Albany and Jeffersonville made it the largest urban area in Indiana. Nearly one in four of all Blacks in the state lived in those

2 Emma Lou Thornbrough, The Negro in Indiana: A Study of a Minority (Indianapolis: Indiana Historical Bureau, 1957), 5. 
three counties as well. ${ }^{3}$ This thesis argues that the social and political development of Floyd, Clark, and Jefferson counties differed from the rest of the state due to their close proximity to Louisville, Kentucky, the largest slave and free-black city of the upperSouth.

But, before the creation of any counties, the territory north and west of the Ohio River entered into United States possession under the terms of the Treaty of Paris of 1783, which ended the American Revolution. Timothy Pickering introduced into the Confederation Congress a proposal to divide the land among Revolutionary War veterans and to prohibit slavery there. In 1784 Congress created a committee to organize the territory. Thomas Jefferson chaired the committee until Congress appointed him as Ambassador to France. Jefferson suggested allowing slavery in the territory until 1800; however, the committee ignored the proposal and Congress did not act until 1787. Small numbers of white people moved into the territory during the next few years and Congress created the Northwest Ordinance in 1787 to insure a governmental structure for those people. Despite the ban on slavery outlined in the Northwest Ordinance, Arthur St. Clair, president of the Congress of Confederation in 1787 and later the first governor of the Northwest Territory, asserted that Article VI of the Ordinance did not free slaves of persons who resided in the territory before 1787. According to St. Clair, Congress intended to prevent the introduction of more slaves into the territory. St. Clair's interpretation soon led to a dispute with George Turner, one of the three judges, who believed the Ordinance freed the three dozen slaves then living in the territory. When Congress received a petition that requested Turner's impeachment, he resigned as judge

3 Census data was obtained from Emma Lou Thornbrough, Indiana in the Civil War Era: 1850-1880 (Indianapolis: Indiana Historical Bureau \& Indiana Historical Society, 1965), 1, 556. 
and left the territory. St. Clair's interpretation prevailed and owners kept their slaves. ${ }^{4}$ Although owners could keep their slaves, Congress did not want slavery extended into the territory, nor did Congress intend for the territory to become a haven for anyone who escaped service. Therefore, Congress added a stipulation that an owner could legally reclaim any person "from whom labor or service is lawfully claimed" who escaped into the territory. ${ }^{5}$

In 1789, when the Constitution of the United States replaced the Articles of Confederation, among other provisions the Constitution also addressed the problems of both fugitives from justice and fugitives from labor. A clause in the Constitution stated that authorities of a state to which a fugitive from service or labor fled must return the fugitive to the state to which he owed service. In 1793, the United States Congress clarified the constitutional clause with an enabling act. The law required the governor of the state to which a fugitive from justice fled to arrest and extradite the fugitive when the governor received a copy of the indictment that charged the fugitive with a crime. In the case of a fugitive from labor, the claimant could arrest the slave in any state or territory without the necessity of a warrant and take him before any United States judge or state magistrate. The claimant could provide oral testimony or an affidavit as evidence. If the testimony convinced the judge or magistrate of the claimant's right to the fugitive, he issued a certificate - a writ of rendition - that authorized the removal of the fugitive to the state or territory from which he had fled. The act provided penalties on anyone who

$4 \quad$ Stephen Middleton, The Black Laws in the Old Northwest: A Documentary History (Westport, Conn.: The Greenwood Press, 1993), 271. Logan Esarey, A History of Indiana from its Exploration to 1850, Vol. 1 (Indianapolis: Hoosier Heritage Press, 1915), 138-139.

$5 \quad$ Annals of Congress, Proceedings and Debates of the House of Representatives of the United States at the Second Session of the Second Congress, 1414-1415. 
obstructed the arrest of, or harbored, or concealed a fugitive. Both the constitutional clause and the law of 1793 linked the rendition of fugitives from justice and fugitives from labor. The authors of both the Constitution and the 1793 Fugitive Slave Law believed that the procedure for the return of fugitive slaves was in the nature of an extradition process rather than a judicial trial; therefore, the law did not provide the judicial safeguards, such as a jury trial, which the Constitution guarantees. However, the 1793 act did establish a process overseen by the state and federal judiciaries and many Northern congressmen believed the provision of the law that required a judge's decision to remand an alleged fugitive protected the free Blacks of their states. The Fugitive Slave Law provided the procedure for the removal of a fugitive to the state from which he fled. Many opponents of slavery disliked the law since it allowed slavery to reach into free states, but it did not allow freedom to reach into slave states. By 1797, New Jersey's representatives were convinced the law did not protect free Blacks and asked for a modification. The rest of the House of Representatives refused. ${ }^{6}$

At the same time the national government passed laws to regulate the Northwest Territory, the United States defeated Natives of the region in a series of wars. White population increased in the territory after the wars of the 1790s. Residents of the eastern portion of the territory soon wished to advance to the representative stage of government outlined in the Northwest Ordinance of 1787. As a result, in 1800 the United States Congress split the area and created the Ohio Territory in the eastern portion and the Indiana Territory out of the west. The earliest laws of Ohio discouraged Blacks from migrating to the territory and signaled that masters in transit through Ohio would not lose

$6 \quad$ Emma Lou Thornbrough, "Indiana and Fugitive Slave Legislation," Indiana Magazine of History (1954): 201-202. Paul Finkelman, Slavery and the Law (Madison, Wis.: Madison House Publishers, Inc., 1997), 116. 
their property. As the pork capital of the West, many Southerners visited Cincinnati to buy supplies, thus Ohio lawmakers adopted policies to appease slaveowners. The early Ohio laws became the model for the rest of the territory. ${ }^{7}$

At the time of the split, the Indiana Territory included the area that later became Indiana, Illinois, Wisconsin, and the western half of Michigan. In January 1801, President John Adams appointed General William Henry Harrison as governor of Indiana. The federal census of 1800 provided Governor Harrison an idea of the area over which he presided. The Indiana Territory included three counties. Knox County, which bordered on the Ohio Territory on the east, Canada on the north, the Ohio River on the south, and the Illinois River on the west, contained 3283 residents. The town of Vincennes held 714 persons, of whom 240 were white males over the age of sixteen. Residents of Vincennes owned eight slaves despite the provisions against slavery in the Northwest Ordinance. Another 819 people lived in the vicinity of Vincennes. In that group were 253 white males over the age of sixteen as well as fifteen slaves. Farther east, in George Rogers Clark's grant north of Louisville, Kentucky, where many of the men were former soldiers who had served under Clark during the American Revolution, the population was 929 . The other 821 residents were scattered around the vast expanse of Knox County. The combined population of the two far western counties, Randolph and St. Clair, was 2358. More slaves, 107, lived in those two counties than in all of Knox County. The total white population of the Indiana Territory in 1800 was 5641. After his

$7 \quad$ Charles Kettleborough, Constitution Making in Indiana, Vol. 1: 1780-1850 (Indianapolis: Indiana Historical Bureau, 1971), 42. Middleton, The Black Laws in the Old Northwest, 1-4. 
first meeting with the three judges of the territory in January 1801, Harrison created Clark County out of the eastern half of Knox County. ${ }^{8}$

Between the time of the creation of Indiana Territory in 1800 and early 1802, the United States Congress and Governor Harrison received three petitions from the two western counties pertaining to slavery. The 270 residents who signed the petitions requested a limited type of slavery and a call for a convention to consider the propriety of repealing the antislavery Article VI of the Ordinance of 1787. Although the Ordinance prohibited slavery in the territory, the Constitution did not. Harrison professed to believe that a majority of the people in the territory favored slavery in some form and acceded to the petitioners. He called for an election of twelve delegates from the four counties to meet at Vincennes on December 20, 1802. The delegates adopted a resolution in favor of a ten-year suspension of Article VI of the Ordinance and asked that Congress grant the request. Committee members believed that the ban forced desirable settlers to move west of the Mississippi River because they could not bring their slaves into Indiana Territory and that legalization of slavery would attract wealthy settlers. The request also proposed that any slaves and their children brought into the territory during the suspension period should remain slaves after the ten years. The two delegates from Clark County opposed the introduction of slavery. The United States Congress did not grant any of the requests of the Vincennes Convention. ${ }^{9}$ Despite this setback to the proslavery movement, Governor Harrison and the three judges decided to take matters into their own hands and permitted a type of indentured service in the territory that opponents argued was a form of slavery. In their legislative capacity, the governor and judges adopted a law in 1803

$8 \quad$ Kettleborough, Constitution Making in Indiana, 42. Barnhart and Riker, Indiana to $1816,318-320,324$.

Barnhart and Riker, Indiana to 1816, 334-335. 
that allowed masters to bring servants, including blacks and mulattoes, into the territory as long as the masters held contracts signed by the servants. The law also granted the masters the right to assign the contracts to others. The indentured service law contrasted with neighboring Ohio. Delegates to the 1802 Ohio state constitutional convention voted to ban both slavery and indentured service. The decision of Governor Harrison and the judges was the first in a series of laws during Indiana's territorial period aimed to circumvent the ban on slavery. ${ }^{10}$

The first period of territorial government in Indiana came to an end in 1804 when Governor Harrison called for a vote on the question of passing into the representative stage of territorial government. Only four hundred settlers voted, but the proposal passed by a 269-131 count. During the representative stage of government, Congress removed legislative powers from the territorial judges and created a council and House of Representatives. Indiana's council consisted of one resident from each of the five counties. President Thomas Jefferson allowed Governor Harrison to appoint the council. By the time the second phase of territorial government began, Congress altered the border of Indiana. Dearborn County in the far east became part of Indiana when Ohio became a state. In addition, the northern border shifted southward when Congress created the Michigan territory. ${ }^{11}$

The first session of Indiana's first elected General Assembly met on July 29, 1805, and continued until August 26. The pro-slavery element passed a bill that allowed any person who owned or purchased slaves outside the territory to bring them into Indiana

$10 \quad$ Francis S. Philbrick, ed., Laws of the Indiana Territory, 1801-1809 (Springfield: Illinois State Historical Library, 1930), 42-46. Nikki M. Taylor, Frontiers of Freedom: Cincinnati's Black Community, 1802-1868 (Athens: The Ohio University Press, 2005), 30 . 11 Esarey, A History of Indiana, 170. 
and bind them to indentured service. If the slaves were over fifteen years of age, the owner could make a contract for service with them for any term of years. The law stipulated that the owner must record the contract with the county clerk within thirty days of the arrival of the slave into the territory. If the slave refused the terms offered him, the master could take him out of the territory within sixty days without losing his title. The law also required owners to register slaves under the age of fifteen with the clerk. However, slaves younger than fifteen could not refuse indenture and must serve until the age of thirty-five if male or thirty-two if female. Children born to slaves after their arrival into the territory must serve the master of the parent until the age of thirty for males or twenty-eight for females. ${ }^{12}$ The law did not indicate the status of children born to the second-generation females who were not yet twenty-eight; however, it is likely the Assembly intended them to be slaves until twenty-eight or thirty as well. Blacks brought into Indiana under the terms of the law faced a dilemma. They could bind themselves for a term of years fixed by their master, which might extend beyond their life expectancy, or their owner might sell them for life outside of the territory. Owners indentured thirty-six blacks in Clark County between 1805 and 1810. The number of years of service varied, but two contracts called for a term of service of 99 years, while others called for 90,70 , 60, and 50; the most common were 40 or 20 years. Residents of Knox County indentured more than fifty Blacks. Many of the prominent families in the territory, including Governor Harrison, owned the services of Blacks under the indenture law. ${ }^{13}$

\footnotetext{
12 Philbrick, Laws of the Indiana Territory, 1801-1809, 136-139.

13 Paul Finkelman, An Imperfect Union: Slavery, Federalism, and Comity (Chapel Hill: The University of North Carolina Press, 1981), 92. Thornbrough, The Negro in Indiana, 11.
} 
The same members of the assembly who passed the indenture bill also sponsored a memorial to the United States Congress. The proposed memorial again asked Congress to revoke Article VI of the Ordinance and also contained a protest against a potential separation of the Illinois counties from the Indiana Territory. However, assembly members from St. Clair and Clark counties formed an unlikely alliance against the petition, and the General Assembly failed to adopt the memorial. Opposition from St. Clair members stemmed from their desire for separation, while Clark County assemblymen opposed slavery. The following year, in November 1806, at the second session of the First Assembly, the legislature passed a bill that allowed owners of contracts made with Blacks under the 1805 law to sell the time of service that remained on the contract. Members also united at the second session to pass another resolution that asked for suspension of Article VI. A Congressional committee reported in favor of the resolution but took no further action at that time. ${ }^{14}$

At the conclusion of the second session, antislavery residents of Clark County held a large mass meeting to take action against the pro-slavery resolutions of the previous two sessions. The meeting concluded with the draft of a memorial for Congress. The memorial stated that Congress should withhold any legislation on the slavery question until the residents of Indiana adopted an anti-slavery constitution supported by a majority of the citizens. At the same time, residents of Dearborn County presented Congress with a petition that expressed their disapproval of the action of the legislature and asked Congress to allow the free state of Ohio to annex the county. The Senate committee that received the resolution of the legislature and the memorial from Clark

14 Barnhart and Riker, Indiana to $1816,349-350$. 
County then reversed itself and reported it inexpedient to suspend Article VI of the Ordinance. The committee took no action on the Dearborn County petition. ${ }^{15}$

Two years later during the second session of the Second Assembly in 1808, General Washington Johnston delivered a report in the territorial House of Representatives on the subject of slavery. Johnston declared that anyone who brought slaves into the territory and held them in slavery until they agreed to a contract of indenture violated the Ordinance of 1787. Johnston further stated that the admission of slavery would be a "retrograde step into barbarism." ${ }^{16}$ A bill to repeal the 1805 indenture act accompanied the report. The House passed the bill; however, the Legislative Council failed to act on it.

While the residents of eastern Indiana Territory denounced the efforts of the slavery advocates, residents of the far western counties continued to send petitions to the United States Congress in support of separation. Congress granted separation on February 3, 1809. The split of the Illinois counties, along with measures that extended the right to vote, altered the political situation in Indiana. Eastern Indiana's population grew from 2517 in 1800 to 24,520 in 1810 . The growth in population came from a mix of settlers from the eastern states who opposed slavery and from the southern states who emigrated because of their dislike of slavery. Representation in the legislature increased for these two groups. The first assembly after the split convened in November 1810. The initiative in governmental affairs passed from the governor to the legislature, and the majority of that body opposed Governor Harrison's programs. The legislature repealed the first section of the 1803 law of the governor and judges that required Black servants

$\begin{array}{ll}15 & \text { Ibid., } 352 . \\ 16 & \text { Ibid., } 354 .\end{array}$


to fulfill their contracts, and also repealed the 1805 act that allowed the indenture of Blacks and mulattoes. Meanwhile, the Illinois counties continued to strengthen their indentured servant laws. ${ }^{17}$

The increase in Indiana's overall population between the time of the federal census of 1800 and the census of 1810 also included an increase in the territory's Black population. The total Black population rose to 630 . However, despite the repeal of the servant laws, most Blacks still labored under contract and the number of Blacks held in slavery increased from 135 to 237. Almost half of the slaves, 108, were in Palmyra Township, Knox County. Knox County still held the largest total population of the four counties, with 7945 residents. The eastern counties of Dearborn and Clark held 7310 and 5670 residents, respectively, while 3595 lived in Harrison County. ${ }^{18}$ The rapid increase in population of the three eastern counties threatened the political influence of Knox County.

Despite the support from white residents of the eastern counties for the repeal of the service laws, many of the whites regarded the migration of free Blacks into the Territory with disfavor. According to Indiana historian Emma Lou Thornbrough, although some of the settlers from the South moved north to get away from the system of slavery, others of these transplanted-Southerners held anti-black sentiments while some wished to bring their slaves with them. ${ }^{19}$ The Indiana territorial legislature recognized the anti-black attitudes and enacted laws to protect the Black population. The same 1810 17 Kettleborough, Constitution Making in Indiana, 54-55. Barnhart and Riker, Indiana to 1816, 355. Louis B. Ewbank and Dorothy L. Riker, The Laws of the Indiana Territory, 1809-1816 (Indianapolis: Indiana Historical Bureau, 1934), 138-139. Middleton, The Black Laws in the Old Northwest, 272-273. 18 Thornbrough, The Negro in Indiana, vii, 22. Barnhart and Riker, Indiana to $1816,361$.

19 Thornbrough, The Negro in Indiana, 7, 20. 
act that repealed the service laws also ordered harsh penalties for kidnapping. Members of the assembly believed the federal Fugitive Act of 1793 made it easy for the unscrupulous to kidnap free Blacks, claim them as fugitive slaves, and receive warrants to carry them away. Indiana lawmakers felt obligated to protect the liberties of free Blacks, but they also needed to uphold the federal laws to return actual fugitive slaves. Therefore, the 1810 law provided that any person who attempted to remove a Black person from the territory must first prove before one of the judges of the court of common pleas or a justice of the peace that he was "legally entitled to do so according to the laws of the United States and of this territory." After such proof of ownership, the claimant received a certificate that authorized the removal. The law proscribed a fine of $\$ 1000$ for failure to comply with this procedure. The intended victim could also sue the kidnapper for damages. ${ }^{20}$ The Indiana law differed from the federal law in two important respects. Indiana required a warrant for the arrest of the alleged fugitive and also guaranteed a trial by jury for the alleged fugitive. However, the legislation did not completely end the crime. According to Thornbrough, "Records from Clark County suggest that the kidnapping of blacks was not uncommon. Several cases arose under the manstealing law, but in no case does a person appear to have paid the penalty which the law imposed." 21

Many residents of Indiana believed that the threat of kidnapping would disappear if fewer Blacks lived in the territory. At the first session of the Fourth General Assembly in February 1813, antislavery and anti-black forces sponsored a bill to prevent the immigration of Blacks into the territory. However, acting-Governor John Gibson

20 Ewbank and Riker, The Laws of the Indiana Territory, 1809-1816, 138-139. 21 Thornbrough, The Negro in Indiana, 95. 
(Harrison resigned to lead the militia against the natives in the War of 1812) vetoed the bill. $^{22}$

By the end of February, President James Madison appointed Thomas Posey to succeed Harrison as governor. Posey served as an officer during the American Revolution, lived for a time in Kentucky, then moved to Louisiana. When Louisiana became a state in 1812, its legislature appointed him as one of their United States Senators. In a letter to Governor Gibson written from Washington a few days after his appointment as governor of Indiana, Posey said he understood that some residents of the territory opposed his appointment because he spent much of his career in slave states. The letter stated that he once owned slaves but emancipated them and that he wished to assure the people that he opposed slavery. He added, "I am sure I shall never sanction a law for slavery or any modification of it." ${ }^{23}$ During Governor Posey's tenure, Black immigration restriction failed a second time. However, territorial laws continued to contain various discriminatory features against free Blacks. Like most states and territories of the time, the legislature limited the right of suffrage to free white males and limited the service of militia duty to white men. The ban on Black militia service copied a 1792 federal statute that limited federal militia duty to able-bodied white citizens. In addition to the voting and military limitations, the territorial legislature enacted a special poll tax of three dollars a year on free black men between the ages of twenty and fiftyfive. The legislature also prevented Blacks, mulattoes, and natives from providing

$22 \quad$ Barnhart and Riker, Indiana to 1816, 416.

23 Ibid., 417. 
evidence in any case except indictments in civil actions in which Blacks, mulattoes, or natives alone were parties. ${ }^{24}$

By early 1816 several members of the Indiana legislature believed the territory was prepared to become a state and petitioned Congress for statehood. However, Governor Posey wrote to Secretary of State James Monroe to oppose the request. Congress ignored Governor Posey's request and passed the Enabling Act. This act provided for the election of delegates to meet in June to determine whether or not a majority of them favored statehood. During the previous ten years in which the Indiana Territory functioned under a semi-representative type of government controlled by the governors, residents made great strides to allow more participation by the people. Residents elected to the territorial legislature a group who opposed the actions of Governor Harrison and they demanded their rights. By the time of Posey's appointment as governor, the legislature dominated the government. The legislature's efforts resulted in the defeat of Governor Harrison's attempt to circumvent Article VI of the Ordinance of 1787 and to legalize slave or semi-slave labor in order to attract settlers from the planter class of southern states. The legislature assured that Indiana would enter the Union as a free state. Statehood promised to bring to a conclusion the struggle of the anti-Harrison party, led by Jonathan Jennings, to democratize the territorial government and to do away with slavery. ${ }^{25}$

Residents of the territory elected 43 delegates to the June 1816 Constitutional Convention. Thirty-four of the delegates lived in slave states before they moved to

$24 \quad$ Ewbank and Riker, The Laws of the Indiana Territory, 1809-1816, 226, 485. Leon F. Litwack, North of Slavery: The Negro in the Free States, 1790-1860 (Chicago: The University of Chicago Press, 1961), 31.

25 Barnhart and Riker, Indiana to 1816, 430, 438, 439. 
Indiana. Twenty-seven lived for a time in Kentucky. On June 10, the opening day of the convention, delegates chose Jennings, a strong opponent of slavery, as the convention president. Most of Jennings's supporters came from the anti-slavery areas of the eastern and southeastern section of the territory. The next day the delegates voted 34-8 in favor of statehood and prepared to write a constitution. ${ }^{26}$

Among other provisions for the state constitution, the delegates addressed the issues of free Blacks and slavery. Although the proposed state constitution granted suffrage to every white male citizen of the United States twenty-one years old or older who resided in Indiana for one year preceding the election, the delegates did not allow either Blacks or women to vote. However, suffrage for all white males represented an advance in democracy for an age when few considered women and blacks qualified to vote. The proposed state constitution also required all able-bodied males between the ages of eighteen and forty-five to serve in militia duty, but banned Blacks, mulattoes, and natives from state military service. ${ }^{27}$

The state constitution provided two protections against the admission of slavery. The territorial legislature rejected slavery and the delegates to the convention showed no disposition to question that decision. In Article XI, Section 7, the delegates banned slavery and involuntary servitude except for the punishment of crimes. The Article also disallowed the importation of indentured Blacks from outside of the state. The second action against slavery came in Article VIII which dealt with the amendment process and stated "But, as holding any part of the human Creation in slavery, or involuntary

26 John Barnhart, "The Southern Influence in the Formation of Indiana," Indiana Magazine of History (1937), 265-271.

27 Kettleborough, Constitution Making in Indiana, 107, 109. 
servitude, can only originate in usurpation and tyranny, no alteration of this constitution shall ever take place so as to introduce slavery or involuntary servitude."28

Despite the bans on involuntary servitude, delegates adopted an important compromise in respect to indentured servants. The original form of Article XI, Section 7, prohibited indentured servitude of adults, except when both parties agreed, and also declared illegal the existing indentures of Blacks whether made within or without the state. The committee of the whole reduced the original proposal to a declaration that no "indenture of any Negro or mulatto hereafter made, and executed out of the bounds of this state [shall] be of any validity within the state." Although the effect of this provision settled the question of future importations, it left pre-existent slavery and servitude open to interpretation. Many residents of the eastern counties who held Blacks in service considered that the provision emancipated slaves and servants and, therefore acted on that theory. However, in the western counties the great majority of masters continued to hold their slaves. Since the Ordinance of 1787 preserved property rights to the French, Canadian, and residents who claimed Virginia citizenship, inhabitants of the western counties believed the Ordinance also secured their right to property in slaves. ${ }^{29}$

The struggle of the early residents of Indiana to escape the undemocratic government of the territorial period led to the framing of the state constitution under which they began their existence as a state. In a time when Congress and state legislatures debated the continuation of slavery, more anti-slavery advocates migrated to the Indiana Territory. These men took the initiative away from Governor Harrison and his followers and prohibited slavery and halted the further introduction of indentured

$28 \quad$ Ibid., $112,117$.

$29 \quad$ Barnhart and Riker, Indiana to 1816, 458. 
servitude when it came their time to create a government. Indiana historian Emma Lou Thornbrough concluded that although the men who framed the Constitution of 1816 were resolute in their determination to rid Indiana of slavery, "they showed no further interest in the rights of colored people." Although no state allowed Black suffrage in 1816, Thornbrough argued that the finished constitution limited the right to vote and the right to serve in the militia to white men. Thornbrough concluded "Both of these provisions had been in force during the territorial period, and neither excited much discussion before the Civil War." ${ }^{30}$ However, Thornbrough's views are tainted by the mid-twentieth century civil rights era in which she wrote. Despite her claims, throughout the post-constitutional era lawmakers fought to free the few slaves and indentured servants who remained in Indiana and also promoted the rights of alleged fugitive slaves who resided in the state. Although lawmakers created a constitution that banned slavery, the issue of slavery in Indiana did not end. Four years after Indiana became a state, the census of 1820 showed both the white and black population concentrated in the river counties along the southern and western border. These areas depended on the trade of slave owners. Indiana followed most states that banned slavery and allowed slave owners to visit or travel through the state with their slaves. In addition, residents of Indiana held 190 slaves in 1820 despite the constitutional ban. The 190 slaves represented a drop of only 47 since 1810. Many Indiana slaveholders believed that the state constitution, like the Ordinance of 1787 , was not retroactive and could not interfere with their preexisting rights. ${ }^{31}$ With its population centered around the city of Vincennes in the west of the state, Knox County contained the largest black population, as well as the largest number

$30 \quad$ Thornbrough, The Negro in Indiana, 120.

31 Finkelman, An Imperfect Union, 147. Thornbrough, The Negro in Indiana, 25. 
of slaves at 118. The southeastern counties of Clark and Jefferson held the second and third largest number of Blacks, 138 and 112 respectively, but no slaves lived in either of those counties. Fifty-one of the remaining 72 slaves in the state resided in the far southwestern counties of Gibson (30), Posey (11), and Vanderburgh (10). Male slaves outnumbered females 98 to 92 across the state. Almost half of the slaves, 83 in total, were under the age of fourteen, while 58 were between fourteen and twenty-six. ${ }^{32}$ Since 141 of the 190 slaves were twenty-six years old or younger, slavery had the potential to exist in Indiana for many more years.

However, Amory Kinney organized a friendly lawsuit to test the slavery provision in the constitution. In 1820, Kinney arranged with Hyacinth Lasselle of Vincennes for Polly, one of Lasselle's slaves, to sue for her freedom. A member of one of the most prominent families in Vincennes and a descendant of one of the earliest French settlers, Laselle replied during the court hearing that Polly was the daughter of a slave he purchased from the natives prior to Virginia's cession of the territory to the federal government in 1784. His lawyers argued that since Lasselle bought Polly's mother before the Ordinance of 1787, the Ordinance did not affect her status as a slave. The Knox County Circuit Court agreed with Lasselle and stated the Ordinance of 1787 could not affect rights that existed before its passage. However, the Indiana Supreme Court rejected the argument unanimously that the French settlers enjoyed rights that could not be destroyed by the state constitution. The higher court asserted that delegates chose to write a state constitution that prohibited slavery. Indiana Supreme Court Judge James Scott wrote, "The framers of our constitution intended a total and entire prohibition of slavery in this State; and we can conceive of no form of words in which that intention $32 \quad$ Barnhart and Riker, Indiana to 1816, 44. 
could have been more clearly expressed" and concluded "under our present form of government, slavery can have no existence in the state of Indiana. ${ }^{133}$ Laselle's attorneys wished to appeal the case to the United States Supreme Court, but Lasselle refused to let the case go any farther. This decision brought to an end the legal question of slavery in Indiana; however, slavery persisted in the state for several more years. A local census taken by order of the Board of Trustees of Vincennes in 1830 showed 32 slaves still resided in that city. The federal census of the same year makes no mention of the Vincennes slaves but it did list one bondsman each in Orange, Decatur, and Warrick counties. The 1840 federal census listed two slaves in Rush County and one in Putnam. ${ }^{34}$ Although the Polly case established that the state constitution abolished slavery in Indiana, it did not deal with the effect of the state constitution on indentures; therefore, authorities in Knox County continued to allow the sale of indentures. In 1821 the Indiana Supreme Court heard an appeal of a servant, Mary Clark, who the Knox County court remanded to her master. In 1815, Benjamin I. Harrison bought Clark as a slave in Kentucky and brought her to Vincennes. Upon their arrival in Vincennes, Clark entered into an indenture with Harrison for thirty years. The month before the constitution of 1816, Harrison manumitted Clark and she signed another indenture with General Washington Johnston on the same day. Clark's indenture with Johnston stated that Harrison freed her at her request and that she agreed of her own free will and accord to a term of twenty years with Johnston. Clark sought her release in 1821, but the Knox County court denied her claim. However, the Indiana Supreme Court reversed the

$33 \quad$ State v. Laselle, 1 Blackford, 60 (1820).

34 Randall T. Shepherd, "Slavery Cases in the Indiana Supreme Court: Where Slaves and Former Slaves Found Hope," Traces of Indiana and Midwestern History (Summer, 2003), 35. Thornbrough, The Negro in Indiana, 25-26, 30. Barnhart and Riker, Indiana to $1816,459$. 
decision. Indiana Supreme Court Judge Jesse Holman held that although Clark signed the contract of her own volition, the mere fact that she applied for release from her indenture provided evidence that the service she rendered became involuntary. Holman wrote that if the state commanded performance from servants it would produce a state of feelings more discordant than slavery itself. Since Clark was of legal age and declared her will in respect to the contract, the law could not contradict that declaration. Although Clark entered into the contracts with Harrison and Johnston before the state constitution took effect, the court interpreted the law broadly enough to cover indentures made prior to the adoption of the constitution. Holman did not make reference in his opinion to the date of the indenture but stated that the mere fact that Clark applied for release provided evidence that the service was involuntary and, therefore, prohibited by the constitution. The decision meant that any adult held under an indenture could apply to a court and gain release. The Knox County court discharged several more Blacks from service in the months following the decision. ${ }^{35}$

While the Indiana courts decided the constitutionality of the ban on slavery and indentures, the state legislature took up the question of fugitive slaves. According to the 1793 federal Fugitive Slave law, a claimant could arrest his alleged fugitive without a warrant in another state and receive a certificate from a federal judge or state magistrate that granted the seized person to the claimant. The law subjected anyone who aided a fugitive or interfered with the capture to stiff penalties. Since slaveowners usually offered rewards for the return of their runaways, the law often led slavecatchers to kidnap free Blacks and claim them as fugitives. In his first address to the first state legislature in $35 \quad$ In re Clark, 1 Blackford, 122 (1821). Thornbrough, The Negro in Indiana, 28-29. Shepherd, "Slavery Cases in the Indiana Supreme Court: Where Slaves and Former Slaves Found Hope," 36. 
November 1816, Governor Jennings urged legislators to consider a measure to prevent the unlawful seizure of free Blacks while at the same time bar from the state any individuals who owed service to citizens of other states. ${ }^{36}$ The assembly responded with "An Act to Prevent Manstealing" which differed from that provided in the federal law of 1793. The Indiana act imposed heavy fines on anyone who knowingly aided escaped slaves, but also afforded personal liberty safeguards not included in the federal law. The new Indiana law forced claimants to obtain an arrest warrant from a judge or justice of the peace and authorized only a sheriff or constable, not the claimant, to make the arrest. After the arrest the justice of the peace or circuit court judge heard all testimony from both claimant and alleged fugitive. The judge set a trial by jury for the next term of the circuit court if he decided that the plaintiff's claim was well founded. If the jury's verdict favored the claimant he received a certificate to carry the fugitive out of the state, but only after he had paid the cost of the trial. The courts subjected any individuals who seized and removed persons contrary to these safeguards to between ten and one hundred lashes, a $\$ 500$ to $\$ 1000$ fine, and labeled them as "guilty of man stealing." ${ }^{37}$

In 1817, shortly after the legislature passed the Act to Prevent Manstealing, Jennings received a letter from Kentucky Governor Gabriel Slaughter. At the request of his legislature, Governor Slaughter protested to Governor Jennings that Kentucky slaveowners experienced difficulties in the reclamation of their fugitives from Indiana. Governor Jennings recommended that the Indiana General Assembly include a provision

$36 \quad$ Logan Esarey, ed., Messages and Papers of Jonathan Jennings, Ratliff Boon, and William Hendricks, vol. 3, 1816-1825 (Indianapolis: Indiana Historical Commission, 1924), 35.

37 Journal of the Senate of the State of Indiana at Their First Session at Corydon, 1816, 75. Emma Lou Thornbrough, "Indiana and Fugitive Slave Legislation," 203-204. Carmony, Indiana 1816-1850, 468. 
to further restrain slaves from fleeing to Indiana to escape their owners, and to enable either circuit or Supreme Court judges to decide such cases with the aid of a jury even when the courts were not in regular session. However, a House committee charged that unprincipled individuals often tried to seize free Blacks and carry them away as slaves and that the free Blacks of Indiana deserved the protection of the laws. Committee members asserted that although all state residents opposed the migration of Blacks into Indiana and that the legislature should restrict further migration, state officials had a solemn duty to protect free Blacks from kidnappers. The assembly later amended the manstealing law to provide a special session of the circuit court and a special jury called to try fugitive cases within three days after the arrest of the alleged runaway, but did not modify its personal liberty legislation. ${ }^{38}$

Indiana lawmakers sought to avoid questions of possible conflict with the federal Fugitive Act of 1793. Legislators included a provision in state policies that allowed claimants to retake fugitives under either the Indiana law or the federal law. However, the procedures for the arrest and trial of runaways varied between the state and federal laws. Because of the discrepancies, some Indiana residents argued that the state law was unconstitutional while others maintained that the Constitution of the United States did not grant Congress alone the power to legislate on fugitives. Therefore, although citizens had an obligation to return slaves, the states, not Congress, should legislate on the subject. ${ }^{39}$ These differences led to two prominent court opinions in 1818.

The first case involved the freedom of a woman named Susan, whom a Kentuckian, John L. Chasteen, claimed as his slave. After the arrest of Susan under the 38 Esarey, Messages, 42. Journal of the House of Representatives of the State of Indiana at Their Second Session at Corydon, 1817-1818, 9-10, 47-52.

39 Thornbrough, "Indiana and Fugitive Slave Legislation," 204. 
Indiana law, the Jefferson County Court in Madison received the case for trial. However, Chasteen signified his intention to take the case to the federal court and asked for the dismissal of the case in the county court. Susan's lawyers then sought an injunction in the Jefferson County court to prevent her removal from the state by Chasteen until her trial under the Indiana law. The Jefferson County judge decided that the case should be tried under the state law and ordered Chasteen to post bond as security that he would not take Susan from the state until such a trial concluded. However, Chasteen ignored this order and sought a warrant from the United States court. In the United States court Susan's lawyers moved for a dismissal of the case on two grounds. First, the fugitive slave clause of the United States Constitution conferred no authority on Congress to legislate on the subject; and second, that even if the court admitted the constitutionality of the federal law of 1793 , the states held concurrent power to legislate on the subject. Federal Judge Benjamin Parke rejected both arguments in an opinion that Indiana historian Emma Lou Thornbrough called "probably the first one handed down by a federal court concerning the constitutionality of the law of 1793."40 Parke's decision not only validated the Fugitive Act of 1793 but his decision also stated that it superseded state laws on the subject. He admitted that states might exert a concurrent power with the federal government on the same subject "for different purposes, but not for the attainment of the same end." ${ }^{41}$ Both Congress and the state prescribed a procedure; therefore, the courts did not need to decide which could best promote the ends of justice. Since Chasteen appealed to the federal law, Judge Parke decided the case must use the federal procedure.

$\begin{array}{ll}40 & \text { Ibid, } 205 . \\ 41 & \text { In re Susan, } 23 \text { Federal Cases, 444-445 (1818). }\end{array}$ 
Although Parke overruled the motion of Susan's lawyers to dismiss the case, he left uncertain what different purposes state laws might cover.

The second case involved both the problems of fugitives from labor and fugitives from justice and began a lengthy altercation between Indiana and Kentucky. A ferry operator who lived near the border of Pennsylvania and Virginia sold a slave named Susan to Richard Stephens of Bardstown, Kentucky. Susan escaped to Indiana in 1815 or 1816 and instituted a suit for her freedom in Harrison County. She claimed her freedom based on her residence in the free state of Pennsylvania. In response to a writ of habeas corpus issued in Harrison County, Stephens replied that he held a bill of sale for Susan that warranted her a slave for life. In August 1818, a jury of the Harrison County Circuit Court ruled in Stephens' favor and returned Susan to him. However, the judge ordered a new trial on a motion of Susan's attorney, and continued the case for several terms of the court. Stephens decided to recover what he regarded as his lawful property with direct action rather than face the delays of the court. A member of the Kentucky legislature and son of Richard Stephens, Robert Stephens came to Indiana with two accomplices and abducted Susan from the Harrison County home where she resided while she awaited the new trial. A Harrison County grand jury indicted Robert Stephens on a charge of manstealing and issued a warrant for his arrest. ${ }^{42}$ Governor Jennings signed a warrant for his extradition from Kentucky in accordance with the part of the federal Fugitive Act of 1793 that dealt with fugitives from justice. However, Kentucky Governor George Slaughter refused to extradite Stephens. In a letter to Jennings, Slaughter stated that the case did not come within the scope of the federal law on fugitives from justice. Governor 42 Nellie Armstrong Robertson and Dorothy Riker, ed., The John Tipton Papers, Vol. 1, 1809-1827, comp. Glen Blackburn (Indianapolis: Indiana Historical Bureau, 1942), 147. 
Jennings replied that in the matter of Stephens the Indiana law was in accordance with the act of Congress and that the state of Kentucky could not decide the constitutionality of an Indiana law. When Governor Slaughter again reiterated that the Stephens case did not comply with the requirements of the act of Congress, Governor Jennings turned over the correspondence with Governor Slaughter to the Indiana legislature. ${ }^{43}$

In response, the legislature passed a resolution that stated that Indiana had a right to enact the manstealing law. If Indiana surrendered the right to prove its citizens free, then it also surrendered an essential prerogative of sovereignty. The legislature concluded that since the federal law of 1793 did not include a provision for punishment, it became both the right and duty of the states to pass laws on the subject whether the laws pleased slaveholders or not. The report requested that Governor Jennings communicate with the President of the United States on the subject of the proceedings. ${ }^{44}$ Accordingly, Governor Jennings forwarded the correspondence with Governor Slaughter on the case of fugitives from justice to Secretary of State John Quincy Adams and requested that he present it to President James Monroe. Governor Jennings later received a letter from Secretary Adams that stated that he had turned the papers over to the President. However, Monroe neither replied nor took any steps to settle this interstate dispute. $^{45}$

Over the next few years, Indiana's lower courts heard other fugitive slave trials that did not become Supreme Court cases. In 1821 a New Albany judge ordered the freedom of a Black child whom a Kentuckian claimed as his escaped slave. The claimant

$43 \quad$ Esarey, Messages, 98-109.

44 Journal of the House of Representatives of the State of Indiana, 1820-1821, 307310.

45 Esarey, Messages, 455-456. 
anticipated such a decision and brought about forty fellow Kentuckians with him to the trial in order to take the child by force. However, the Indiana authorities anticipated the attempt. The Floyd County sheriff and a group of militia intervened when the Kentuckians attempted to seize the child and a free-for-all fight ensued. Someone knocked the judge out, but the court officers saved the child from abduction. ${ }^{46}$ Although the case did not advance to the Indiana Supreme Court, it reflects the concerns that Indiana residents had for the growing issue of fugitives from service.

Governor Jennings continued to support Indiana's laws that protected Blacks during his entire tenure in office despite the turmoil with Kentucky's citizens and state government. In 1820, outside of his official duties as governor, Jennings helped to found the Indiana Colonization Society. Other members of the society elected him as president. At its organizational meeting, the society condemned slavery, urged Indiana citizens to check its extension, and adopted a constitution that advocated the colonization of Blacks to Africa. As governor, Jennings appointed the judges who supported Blacks and also urged the legislature to protect Blacks. By 1824, anti-slavery legislation and judicial decisions led to the security of blacks in Indiana. However, neither of Jennings's successors, acting-Governor Ratliff Boon nor elected Governor William Hendricks, pressed for Black rights as vigorously as Jennings. Neither Boon nor Hendricks renewed the application for Robert Stephens's extradition after Jennings resigned as governor in late 1822 to replace Hendricks in the United States House of Representatives. In June 1823, the inaction of Boon and Hendricks led the Harrison County court to dismiss the 
case against Robert Stephens. ${ }^{47}$ The following year, the Indiana legislature began to shift away from Black rights and make concessions to slaveholders of the South.

$47 \quad$ Donald Carmony, Indiana 1816-1850: The Pioneer Era (Indianapolis: Indiana Historical Society, 1998), 469. 


\section{CHAPTER 2}

\section{REPRESSION, 1824-1850}

When the Indiana legislature enacted the controversial Manstealing Act of 1816, it expressed a genuine concern about the protection of the rights of their Black residents. However, in 1822, the position of Blacks in Indiana changed after Governor Jonathon Jennings left office. In 1824, the state legislature shifted away from the recognition of Black rights and passed laws to make it easier for Southern slaveholders to claim their fugitives. Over the next twenty-six years, lawmakers limited rights of free Blacks who moved into the state. Chapter two of this thesis discusses the state legislature's shift away from Black rights after 1824 and the judicial decisions that reinforced the shift. The chapter argues that legislative action and judicial decisions led to increased violence in southeastern Indiana between those who continued to aid Blacks and a growing number of anti-blacks as the population increased during the next two and a half decades.

In 1824, the General Assembly revised its personal liberty legislation. The new law made concessions to southern slaveholders and proved less favorable to Blacks claimed as fugitives. Judge Benjamin Parke supervised the revision of the law. ${ }^{1}$ Two years earlier, Judge Parke decided the constitutionality of the Fugitive Act of 1793 and that the act superseded state laws in in re Susan discussed in Chapter 1. Under the new

1 Emma Lou Thornbrough, The Negro in Indiana: A Study of a Minority (Indianapolis: Indiana Historical Bureau, 1957), 99. 
law, which avoided the word "manstealing," the legislature allowed the claimant to secure a warrant from any county clerk and to make the arrest himself, whereas the earlier law required that a sheriff or constable make the arrest. After arrest, the claimant must take the alleged fugitive before a justice of the peace or a circuit court judge. The presiding magistrate must hold a trial and determine the case within sixty days after the arrest. The claimant received a certificate that authorized him to carry the fugitive out of the state if the hearing officer decided in favor of the claimant. Either party might appeal the decision, but the law required the appellant to pay the cost of the first trial and to give security for the cost of the appeal in advance. These financial requirements made it difficult for Blacks to appeal. In addition, the law required the alleged fugitive to give security for his appearance at the new trial or be jailed in the interim. Only at the second trial did the law require the judge to summon a jury to hear the case, which he must do within five days of his original decision. The act provided fines not to exceed $\$ 500$ and damages to the injured party on any person who gave false certificates of emancipation, or who knowingly harbored or employed a slave, or obstructed the recapture of a fugitive. The procedure prescribed by the 1824 law conformed more nearly to that of the federal law of 1793 than did the procedure provided in the state law of 1816 . The change led to the abandonment of personal liberty laws in Indiana by the end of the decade. However, the revised laws also contained stiffer penalties for kidnapping. Penalties included fines of from $\$ 100$ to $\$ 5000$ and imprisonment of from one to fourteen years for anyone who forcibly removed any person without a proper claim. ${ }^{2}$ In spite of the protection outlined by the penalties, kidnappers continued to seize and carry blacks into slavery without an

$2 \quad$ The Revised Statutes of the State of Indiana, 1824, 221-222. 
opportunity to prove their right to freedom. Kidnappings occurred most frequently in the counties near the southern border where larger numbers of blacks resided in Indiana. ${ }^{3}$

The kidnappings corresponded to the increase in the Black population of Indiana during the 1820s. The number of Blacks in Indiana rose by 1212 in the 1820 s, as compared to an increase of 193,641 in the white population during the same decade. Although the Black population increased a small amount, many of the new arrivals settled in the southern counties. The main source of the new Black arrivals was North Carolina. During the 1780s and 1790s every southern state except North Carolina passed laws that allowed slaveowners to emancipate their slaves. However, some North Carolina slaveowners ignored the law and freed their slaves. Others who wished to free their slaves did not want to create a free Black society in the state. The Quakers of North Carolina appointed a committee to examine the laws of the free states to determine if those states allowed the admission of Blacks. The committee reported in 1823 that Ohio, Indiana, and Illinois did not have laws to prevent Blacks and recommended the removal of their Blacks to those states. ${ }^{4}$ A second source came from Kentucky slaveholders who brought old or feeble slaves to Jefferson and other river counties to free them. Since they could not work they became the charges of the people of Madison. ${ }^{5}$ Due to the increase in the Black population and the increase in the number of kidnappings, proposals to the legislature to prevent the immigration of Blacks into Indiana and to compel those already in the state to go to Liberia found a receptive audience by the end of the decade.

3 Thornbrough, The Negro in Indiana, 99-100.

$4 \quad$ Wilbur H. Siebert, The Underground Railroad from Slavery to Freedom (New York: Russell \& Russell, 1898), 93. Ira Berlin, Slaves Without Masters: The Free Negrom in the Antebellum South (New York: Pantheon Books, 1974), 29-32. Thornbrough, The Negro in Indiana, 39. 
In 1831, the state legislature acted on the proposals to end Black immigration. The Indiana House of Representatives passed a bill that required every Black who came into the state to have a certificate of freedom. The bill further required the county sheriffs to hold any Black who did not have a certificate and advertise him as a fugitive. This bill did not pass the Senate. However, in 1831 the legislature did adopt a policy that required Blacks who came into the state after the ratification of the law to post a five hundred dollar bond as a guarantee against becoming a public charge and as a pledge of good behavior. Conviction of a crime or misdemeanor meant forfeiture of the bond. Overseers of the poor could either remove from the state anyone who did not pay the bond or hire that person out for a period of six months. The law also fined anyone who knowingly hired or harbored a Black who did not pay the bond. ${ }^{6}$

The Indiana Supreme Court, which lost anti-slavery justices Jesse Holman and James Scott in 1830, upheld the law on three different occasions. In the first case, Judge Amory Kinney released a man who failed to pay the bond. Kinney defended Polly in State v. Lasselle discussed in Chapter 1. On appeal of Kinney's release of the man, the state Supreme Court decided "it is our duty to decide in favour of the validity of the statute, unless its unconstitutionality is so obvious as to admit of no doubt," and that the law was "not so clearly repugnant to the constitution as to authorize us to pronounce it a nullity." ${ }^{7}$ In the second case, George Baptiste, a mulatto barber in Madison, was the principal figure. White residents of Madison suspected Baptiste, who moved to the city around 1838 without paying the required bond, of aiding fugitives. The next year, a justice of the peace ordered Baptiste to comply with the requirement and the circuit court

$6 \quad$ Journal of the House of Representatives of the State of Indiana, 1830-1831, 247248. The Revised Statutes of the State of Indiana, 1831, 375-376.

$7 \quad$ State v. Cooper, 5 Blackford, 258-259. 
at Madison affirmed the ruling. The court ordered the removal of Baptiste "to the state where he last legally resided." ${ }^{8}$ The Indiana Supreme Court ruled the original expulsion order as procedurally deficient since it failed to specify Baptiste's last legal residence; however, the court allowed the statute to stand. The third case involved Thomas Hickland, a member of a white Jennings County family known for their antislavery views. A jury in Vernon found Hickland guilty of knowingly hiring a Black who entered the state after 1831 and had not posted bond. Hickland appealed, but once more the Supreme Court upheld the validity of the statute and sustained the action of the lower court. $^{9}$

Although few Blacks paid the bond, officials in Clark County began a concerted effort to compel Blacks who resided there to pay. Some Blacks who could not raise the money moved from the county. Alarm spread to officials in neighboring Floyd County who feared Clark County Blacks might settle there. The New Albany Ledger urged officials to follow the example of the Clark County officers. "Would it not be well for our own officers to enforce the same provisions against this class?" asked the Ledger. "If not, we shall soon be overrun with all the worthless, idle, and dissolute Negroes in the surrounding counties," the paper continued. ${ }^{10}$

Colonization also appealed to the white citizens of Indiana as well as the bond requirement as a means of ridding the state of its Black population. Created in 1820, the state's original colonization society disbanded shortly after its first meeting. However,

8 Baptiste v. State, 5 Blackford, 283-288.

$9 \quad$ Hickland $v$. State, 8 Blackford, 365-366. See also, Thornbrough, The Negro in Indiana, 59-61; Randall T. Shepherd, "Slavery Cases in the Indiana Supreme Court: Where Slaves and Former Slaves Found Hope," Traces of Indiana and Midwestern History (Summer, 2003), 36-38.

$10 \quad$ New Albany Daily Ledger, 10 August 1850. 
the Indiana Colonization Society reorganized in Indianapolis in November 1829. The society took collections in churches on or near the Fourth of July each year to help finance colonization efforts. At the 1830 annual meeting, the managers of the society exalted Liberia as a place for colonization. ${ }^{11}$ According to E.S. Abdy, an English traveler who visited Black settlers near Madison in the early 1830s, as long as early communities needed workers to clear land, settlers welcomed Blacks. But as population grew and land value increased, Blacks found it more difficult to acquire land. A Black who arrived in Jefferson County from Kentucky in the early 1830s told Abdy that he wanted to buy land in the community but found such hostility among whites against Blacks that he doubted whether he could. Abdy's Black host told him that whites treated him well when he moved to the county, but after a short time his neighbors plagued him and his family with their efforts to persuade him to sell his land to them and move to Liberia. Abdy concluded that Blacks resented the attempts at colonization since the only recommendation for it was that it lessened their numbers and perpetuated their degradation. Opposition to colonization led to the first known state convention of Indiana Blacks during the winter of 1841-1842 in Madison. The delegates expressed opposition to African colonization, but they showed an interest in the possibility of Blacks migrating to the Oregon country. ${ }^{12}$

In 1831, along with the bond requirements enacted by the Indiana legislature, the lawmakers also passed education reforms. Education developed slowly in pioneer Indiana despite provisions in the Ordinance of 1787 that guaranteed funds for the creation of public schools. Despite the slow start, due to the overwhelming population increase 11 Donald Carmony, Indiana 1816-1850: The Pioneer Era (Indianapolis: Indiana Historical Society, 1998), 563.

12 Thornbrough, The Negro in Indiana, 79-80, 138. 
and the stabilization of the economy throughout the 1820s, more Indiana families began to support public schools. The early school laws made no mention of color, but in 1832 the state Senate questioned whether Black property holders could participate in school elections. ${ }^{13}$ A report of the judiciary committee asserted that every resident, regardless of color, had a right to participate in the school fund and to have a voice in the ways and means in the supporting of the schools. However, in 1837 the legislature revised the law to allow only white inhabitants to carry out the provisions of the school act. A later act permitted householders of a district to levy a special tax for school purposes, but exempted the assessment of property owned by Blacks. Although neither act denied school attendance to Blacks, both made the implication that Indiana public schools were for whites. The legislature further incorporated this implication in 1843 in a provision that declared that public schools were open to white children between the ages of five and twenty-one. The same act of 1843 required masters of apprentices to give some training in reading, writing, and arithmetic. A later amendment gave the masters of Black apprentices the option of ignoring this requirement since those children could not attend the public schools. Indiana's education laws contrasted with its neighbor Ohio. In 1849 the Ohio legislature overturned that state's Black Laws and also created public schools for Blacks. Furthermore, the act allowed Black property owners the right to vote for school board members. ${ }^{14}$

Except for school laws the only other important racial distinction in Indiana law was found in marriage laws. Lawmakers did not take any particular interest in the matter 13 Journal of the Indiana State Senate, 1831-1832, 186, 239-240. 14 The Statutes of the State of Indiana, 1836-1837, 15. The Statutes of the State of Indiana, 1840-1841, 82. The Revised Statutes of the State of Indiana, 1843, 320. The Statutes of the State of Indiana, 1849-1850, 141. Nikki M. Taylor, Frontiers of Freedom: Cincinnati's Black Community, 1802-1868 (Athens: Ohio University Press, 2005), 165. 
until 1840, when they passed a drastic law on the subject. The bill "to prohibit the amalgamation of whites and blacks" which passed the legislature prohibited marriages between whites and persons who had one-eighth or more of Black blood. Penalties included fines up to five thousand dollars and prison terms of ten to twenty years for persons who married in violation of the law. Further penalties included a fine of five hundred dollars for county clerks who issued marriage licenses contrary to the law, and a fine up to ten thousand dollars for ministers who performed marriage ceremonies. ${ }^{15}$

At the same time that Indiana began to limit the rights of Blacks, a second Great Awakening occurred around the United States. Those whom the Awakening affected sought to revolutionize living and working society. They declared slavery as one of the worst institutions in the United States and organized themselves into antislavery societies to address the abomination of slavery. These societies confined their efforts to legal measures during their early years and refrained from violating even the laws that seemed to support slavery. In many states they pushed to change laws and urged legislatures to pass personal liberty laws that forbid state officials from assisting in the capture and return of runaway slaves. Hostility to slavery grew as more nonslaveholding whites moved into the northwest. Many northwesterners believed that the continuation of slavery in the South would spawn a large free Black population who would compete with whites for land and resources. This group believed that Southerners released their most troublesome and unproductive slaves if they agreed to move north of the Ohio River. Thus, antislavery sentiment became intertwined with anti-black beliefs in some abolitionist societies. Various groups around Indiana created about a dozen antislavery 15 Journal of the House of Representatives of the State of Indiana, 1839-1840, 196198. The Statutes of the State of Indiana, 1839-1840, 32-33. The Statutes of the State of Indiana, 1840-1841, 128. The Statutes of the State of Indiana, 1841-1842, 142. 
societies by the early 1840s. Two of the earliest societies formed in Jefferson County. In 1836, a group of nine students at Hanover College, a Methodist affiliated school, created a society with a constitution that affirmed the right of slaves to be free and the right to enjoy their freedom anywhere in the United States. In 1839, members of the Lancaster Baptist Church near Madison in northern Jefferson County created the Neel's (sometimes Neal's or Neil's) Creek Anti-Slavery Society. However, most of the societies around the state were short lived and they did not influence the actions of the legislature. ${ }^{16}$

The antislavery advocates who feared competition from free Blacks began to see those fears realized. The Black population in Indiana increased by 4536 during the $1830 \mathrm{~s}$ and by 4094 in the 1840s despite the 1831 law that required new Black arrivals to pay a bond and the other legislative acts that discriminated against them. More than half a million whites moved into the state in the same two decades. The same expansion of job opportunities that attracted whites to Indiana also attracted the free Blacks who migrated to the state. Blacks who moved into Indiana in this period fell into three general groups. The first group lived as free people in the states in which they resided before they moved to Indiana and the second group consisted of recently emancipated slaves who fled the slave states. Free Blacks in Indiana lived with the legal prejudice of whites; however, the fear of kidnapping held more importance to them than prejudice. The third group was fugitive slaves who were not considered free in any state. Even though they settled in a 16 Robert Remini, At the Edge of the Precipice: Henry Clay and the Compromise that Saved the Union (New York: Basic Books, 2010), 9. Larry Gara, The Liberty Line: The Legend of the Underground Railroad (Lexington: University of Kentucky Press, 1961), 70. Joe William Trotter, River Jordan: African American Urban Life in the Ohio Valley (Lexington: University of Kentucky Press, 1998), 25. Emma Lou Thornbrough, Indiana in the Civil War Era, 1850-1880 (Indianapolis: Indiana Historical Bureau, 1965), 19, 20. Thornbrough, "Indiana and Fugitive Slave Legislation," 218. Carmony, Indiana, 1816-1850, 566. William S. Dow, comp., Negroes in and Around Jefferson County, Indiana, (Madison, In.: Jefferson Co. Historical Society, 1950), 2, 20-22. 
free state, the laws still considered them as slaves subject to recapture and return to slavery. $^{17}$

Free Blacks moved into Indiana for economic purposes. The barber trade provided free Black men their most promising opportunity to earn a living, purchase real estate, and increase their standing in Ohio Valley cities. Some Black barbers, cooks, and caterers gained a substantial economic footing by serving an elite white clientele. The social contacts of Blacks who catered to white elites allowed them to amass resources, power, and prestige that enabled them to protect themselves better than their workingclass and poor counterparts; however, it failed to shield them from racism. Either by custom or by law, restaurants, theaters, hotels, and other public accommodations barred all Blacks or served them on a segregated and unequal basis. ${ }^{18}$

Indiana's free Black population developed a stronger fear of kidnapping when the legislature revised the manstealing laws. If whites could mistakenly identify every fugitive from service as a legal resident of the state, they could just as likely mistakenly identify every free Black as a runaway. Kidnappers and agents of slaveholders menaced blacks in southern Indiana. According to historian Keith Griffler, "the black population of Madison could identify professional kidnappers by sight." In an effort to protect themselves some free Blacks recorded certificates in county courts that attested to their freedom, although state law did not require them to do so. Others carried freedom certificates with them when they traveled. Despite these efforts, in some instances kidnappers forcibly removed free Blacks from the state, at times without a hearing before

17 Thornbrough, The Negro in Indiana, 32, 39, 44. Trotter, River Jordan, 26.

18 Trotter, River Jordan, 33, 38-39, 51. 
an appropriate official. At other times, claimants falsely persuaded judges that free Blacks were their slaves. ${ }^{19}$

No records exist of the numbers of Blacks who kidnappers carried into slavery, but in at least three cases in southeast Indiana the community intervened when illegal enslavement occurred. In the early 1840 s a Black who claimed to be a freeborn resident of Cincinnati befriended men near Madison as he traveled overland from New Albany to his home. The men decoyed him into a private dwelling with an offer of food and shelter then seized him, carried him to Kentucky, and collected a reward. A friend later tracked the captive to a Kentucky jail and proved that he was free. The other two cases occurred near Cincinnati at Lawrenceburg. In 1843 two constables of Lawrenceburg arrested two free blacks. Since Kentucky law provided a reward for the capture of fugitives, the constables carried the pair across the river where the lawmen signed affidavits that stated they seized the Blacks as runaways. However, the abduction aroused the people of Lawrenceburg to the point that they offered a reward for the capture of the constables who had disappeared. The second attempt at forcible seizure in Lawrenceburg involved a man who moved to that city in the late 1830s. In 1845 kidnappers seized him without a warrant and prepared to take him to a justice of the peace to obtain a certificate for his removal from the state. Before they could obtain the certificate, a local merchant secured legal counsel for the man. A judge gave the counsel thirty days to gather evidence and confined the man to jail in the meantime. At the trial the men who seized him produced evidence to show that he escaped from his New Orleans owner seven years earlier. The

19 Keith Griffler, Front Line of Freedom: African Americans and the Forging of the Underground Railroad in the Ohio Valley (Lexingotn: The University of Kentucky Press, 2004), 7, 19. Thornbrough, The Negro in Indiana, 103. Col. William M. Cockrum, History of the Underground Railroad (New York: Negro Universities Press, 1915), 9. 
judge decided that in a free state the law presumed every person as free regardless of color. Therefore, the claimants must not only prove the man was once a slave, but also prove that no subsequent act freed him. Since the claimants did not provide such evidence, the judge released the man. ${ }^{20}$

The third group of Blacks who entered Indiana did so illegally. These actual fugitives from service faced even harsher treatment than the free Blacks. Historians estimate that at least 100,000 slaves escaped between 1810 and 1850. Wilbur H. Siebert, who made one of the earliest studies on the subject of fugitives in Indiana, distinguished three main routes along the Ohio River that fugitives used to enter the state. Two of the routes were in the far eastern and far western points of Indiana, near Cincinnati, Ohio and Evansville. The third area of entry, in the vicinity of Louisville, Kentucky, contained multiple branches, which included Madison, Jeffersonville, and New Albany. Small numbers of Black and white residents of Indiana aided fugitives. The best known Blacks who aided runaway slaves lived in Madison and the Black settlement of Graysville near Hanover in Jefferson County. A Black Masonic lodge in Louisville led fugitives into New Albany and Jeffersonville. ${ }^{21}$ As a result, Madison, Jeffersonville, and New Albany became centers of activity for both anti-Blacks and residents of the state who supported Blacks.

Until the late-1840s Madison was the largest city in Indiana. Geography and geology both played an important role in the development of the city. Geographically, Madison is located between Cincinnati, gateway to the West, and Louisville, gateway to 20 Thornbrough, The Negro in Indiana, 105-107. 21 J. Blaine Hudson, Fugitive Slaves and the Underground Railroad in the Kentucky Borderland (Jefferson, North Carolina: McFarland and Co., Inc, 2002), 4. Wilbur H. Siebert, The Underground Railroad from Slavery to Freedom (New York: Russell and Russell, 1898), 137-138. 
the South. Madison's location led it to become a thriving regional market town with a major landing port for all types of river vehicles. Along with river travel, the Jeffersonville-Madison-Indianapolis railroad helped provide the city with a base of economic wealth and a well-developed commercial and industrial center. The sizeable number of attorneys, judges, and busy court calendar helped Madison become the early giant in Indiana politics, and it maintained its predominance until the population centers moved north and west after the Civil War. The free Black population built rapidly at Madison in large part because the city was such a vital economic center for the region. Geologically, a large bend occurs in the river west of Madison at Hanover. The bend caused large sandbars, which permitted easier river crossings for fugitives. At some points of the year, runaways could walk across the river; at other times, swimming was possible. In September 1849, the river was so low that it halted all boat traffic and people waded across the river at Madison. In addition, large ravines and limestone caves south of Hanover at Saluda permitted runaways some degree of cover until they reached the Hanover plain. ${ }^{22}$

In the mid-1830s, several skilled free Blacks from Virginia moved to Madison. Blacks of Madison lived less than half a mile from the Ohio River in a section of the city called Georgetown. One of the arrivals, George Baptiste, owned a barbershop on the same block as the Jefferson County Courthouse and served many of Madison's white judges and lawyers. Baptiste, William Anderson, Elijah Anderson, Griffin Booth, Chapman Harris, and other Blacks became more aggressive and better organized

$22 \quad$ Diane Perrine Coon, Southeastern Indiana's Underground Railroad Routes and Operations: A Project of the State of Indiana Department of Natural Resources, Division of Historic Preservation and Archaeology and the U.S. Department of the Interior, National Park Service (Bloomington: Perinne Enterprises, 2001), 25-26, 29. 
throughout the 1840s in their assistance of fugitives through Madison. Whites in Madison who aided fugitives included J.H. Tibbets and John Todd. Todd's house included secret chambers in order to shelter runaways. Meanwhile, in Floyd County, Blacks who lived in the West Union section of New Albany and the mixed race congregation of the Second Presbyterian Church actively assisted fugitives out of Louisville. Communities that contained large numbers of fugitives developed in other areas around the state, especially in the southeast. One of the largest settlements of fugitives developed north of Jefferson County at Jennings County. The settlement grew so rapidly that other residents of the county called the area "Africa.",23

The legal system also sympathized with the runaways at times. Some officials maintained that as a free state, Indiana offered a protection of legal rights. An Indianapolis judge, confronted with a Virginian's claim for the return of four fugitives, responded that the owner's voluntary entrance into a free state rendered those slaves free. Another magistrate participated in a slave rescue. In Salem, the seat of Washington County, a justice of the peace delayed a fugitive's trial in order to give anti-slavery activists time to release the man from jail. Opponents of the slave catchers freed the prisoner and furnished him with a pair of horses. ${ }^{24}$

However, legal aid to fugitives appeared to end in 1842 with the United States Supreme Court's decision in Prigg v. Pennsylvania. In 1837, a Pennsylvania court convicted Edward Prigg of kidnapping after he seized a Maryland slave and her children

23 Darrel E. Bigham, On Jordan's Banks: Emancipation and its Aftermath in the Ohio River Valley (Lexington: The University of Kentucky Press, 2006), 47. Dean J. Kotlowski, "'The Jordan is a Hard Road to Travel': Hoosier Responses to Fugitive Slave Cases, 1850-1860," International Social Science Review 79 (Fall/Winter, 2003), 74. Coon, Southeastern Indiana's Underground Railroad Routes and Operations, 49. Thornbrough, The Negro in Indiana, 48.

24 Kotlowski, "The Jordan is a Hard Road to Travel," 73. 
and removed them from Pennsylvania. The woman's owner allowed her to live as a free person but never emancipated her. She married and had several children born in the free state of Pennsylvania. When the owner died, his heirs hired Prigg to return her and her children to Maryland. Pennsylvania authorities arrested Prigg for violation of the state's anti-kidnapping law. In a complex decision, the Court declared Pennsylvania's antikidnapping law and other state's laws that interfered with the return of fugitives slaves as unconstitutional; upheld the federal fugitive law of 1793; and affirmed that a slaveholder could compel the return of his property without relying on any statute or judicial procedure. The Court also declared that local officials could aid slaveholders in the return of their fugitives unless state laws prohibited the aid. Many people in the non-slave states believed the decision threatened the peace since it did not provide them with the legal authority to prevent kidnapping of free Blacks and left all Black residents vulnerable. As a result, between the time of the decision and 1850 nine states passed personal liberty laws that denied the use of state facilities and officers to federal authorities. In addition, Ohio repealed its law that required state officials to enforce the Fugitive Slave Act. ${ }^{25}$

However, the Indiana House of Representatives believed the Prigg decision meant that existing state laws were unconstitutional and the state government could not legislate either for or against the master or slave on the subject of fugitives from labor. The Indiana Supreme Court determined the constitutionality of state law in two decisions

25 H. Robert Baker, Prigg v. Pennsylvania: Slavery, the Supreme Court, and the Ambivalent Constitution (Lawrence: The University of Kansas Press, 2012), 1. Paul Finkelman, "Prigg v. Pennsylvania and Northern State Courts: Anti-Slavery Uses of a Pro-Slavery Decision," Civil War History 25 (1979), 6, 8. Paul Finkelman, Slavery in the Courtroom: An Annotated Bibliography of American Cases (Washington: Library of Congress, 1985), 60-64. Paul Finkelman, "Story Telling on the Supreme Court: Prigg v. Pennsylvania and Justice Joseph Story's Judicial Nationalism," Supreme Court Review (1994), 252-253. 
based on the Prigg case. The first case occurred in Elkhart County in extreme northern Indiana in connection with the capture of an alleged fugitive. Claimants arrested a Black man under the authority of a warrant issued by a justice of the peace. However, a riot broke out when the claimants took the alleged fugitive before a magistrate. Authorities arrested the claimants for their part in the riot. At their trial, the circuit court judge instructed the jury that under Indiana law the claimants could not seize the fugitive without a state issued warrant and that the warrant issued by the justice of the peace could not protect them. The jury found them guilty. However, on appeal the state Supreme Court declared the judge's instructions varied from the doctrines of the United States Supreme Court's decision in Prigg v. Pennsylvania and reversed the guilty verdict. ${ }^{26}$

In the second case, a slave woman and her children reached Decatur County after they escaped from Kentucky. A white man named Luther Donnell hid the family until they made their way to Canada. Decatur County authorities charged and convicted Donnell for violation of the state law that made it illegal to induce a slave to run away or to hide a slave. However, based on Prigg v. Pennsylvania the Indiana Supreme Court ruled the state law unconstitutional since enforcement of the Fugitive Act of 1793 belonged to the federal government alone. This decision overturned Donnell's conviction. $^{27}$

After the 1831 Indiana law that required Blacks to pay a good behavior bond, anti-black residents created more devices intended to aid the recapture of runaways. For instance, rewards for fugitive slaves increased from about twenty dollars in 1818 to over one hundred dollars in 1830. Owners employed full-time slave catchers and detectives,

26 Thornbrough, "Indiana and Fugitive Slave Legislation," 219-220. Graves et al v. State 1 Porter, 368-373 (1849).

$27 \quad$ Donnell v. State 3 Porter 481 (1852). 
and they raised posses that raided the suspected locations of their slaves in Indiana. In the late 1830s, the Indiana legislature also passed a resolution to combat the assistance of fugitives. The resolution stated that interference with the capture of fugitives "is highly reprehensible, unpatriotic, and injurious to the peace and stability of the union of the states." 28 While a small number of people of the state aided the fugitives, others admitted the slave owner's rights to reclaim their property and aided the owners by acting as spies or informers. The pursuit of slaves attracted wide attention by the middle of the $1830 \mathrm{~s}$ and southern Indiana became what the abolitionists called the "hunting-ground." In northern Jefferson County a radical pro-slavery group formed with the intent to catch and return fugitive slaves and recaptures in the area became numerous. ${ }^{29}$

The anti-black element became more active in southeastern Indiana after the Prigg decision. The battle between the forces of freedom and the forces of slavery became most heated and most violent in Madison. Proslavery southerners believed Madison was the main entry point of fugitives and determined to stop the flow there. Indiana Governor James Whitcomb turned over William Anderson, a Black resident of Madison, at the request of Kentucky Governor William Owsley on charges that Anderson conspired to help slaves escape. The prisoner's friends obtained a writ of habeas corpus to hear the case in an Indiana court; however, Kentucky authorities refused to return him. They threatened to shoot the deputies who served the writ and the deputies returned to Madison without Anderson. The following year, in 1846, a mob of more than one hundred proslavery whites attacked Madison's Black community without warning. The

$28 \quad$ The Statutes of the State of Indiana, 1839, 353.

29 The Statutes of the State of Indiana, 1839, 353. Siebert, The Underground Railroad from Slavery to Freedom, 240. Coon, Southeastern Indiana's Underground Railroad Routes and Operations, 37. 
mob ransacked homes and businesses in an attempt to find fugitives and weapons. The mob carried Griffin Booth, one of the leaders of the city's Black community, to the river and repeatedly held him under water to get him to reveal the whereabouts of a group of fugitives. Two white antislavery activists saved Booth from drowning. Another Black leader of Madison, George Evans, faced a public lynching from the mob. A white businessman held the vigilantes at gunpoint and saved Evans. The mob then attacked an elderly Black man who held the attackers at bay until his ammunition ran out. Once he became defenseless, he suffered a life threatening beating from the mob. After the attack, many of Madison's most well-known Blacks who aided fugitives fled the city. George Baptiste, the barber, moved to Detroit. Griffin Booth fled to Canada, while Elijah Anderson relocated to Lawrenceburg. ${ }^{30}$ Mob violence also affected Jeffersonville. White citizens of that city accused two Black men of consorting with white women. A mob gathered and tied the two men to posts. The group then whipped the men in the presence of a large crowd. ${ }^{31}$

The increase in captures of fugitives led southern slave owners to call for a tighter federal Fugitive Slave Law, while the escalation of violence led many white citizens of Indiana to call for more restrictions on the Black residents of the state. In 1850, the United States Senate began debate on a new fugitive law and the Indiana legislature called a convention to update the state constitution. By the end of the year, both the federal government and the Indiana state government believed they settled their issues in regards to Blacks.

$30 \quad$ Madison Courier, 5 July 1889. Negroes in and Around Jefferson County, 11, 30$32,39$.

New Albany Daily Ledger, 3 August 1850. 


\section{CHAPTER 3}

\section{SLAVE CATCHERS AND EXCLUSION, 1850-1860}

By 1850, many slave owners believed the federal government needed to enact stricter fugitive slave measures despite the increased efforts of anti-black forces to aid in the return of fugitives during the previous decade. At the same time, anti-black leaders in Indiana sought ways to end the racial turmoil that had grown in the state since the mid1820s. By the end of 1850 , both the federal lawmakers and leaders of Indiana believed they had created a solution to their racial problems. Throughout 1850 , members of the United States Congress debated several measures aimed to avert a crisis that threatened to split the Union. The result of the nine-month long fight was the Compromise of 1850. One piece of that compromise was a new federal Fugitive Slave Law. One month after the national Congress passed the compromise measures, during the fall of 1850 , delegates in Indiana met to write a new state constitution. The Constitution of 1851 banned further Black immigration into the state. This chapter analyzes the passage of the new federal Fugitive Slave Law and Indiana state constitution and argues that neither was effective.

Slave owners believed that northerners assisted runaways and they also believed that many weaknesses existed in the Fugitive Slave law of 1793. The law allowed the owner of a fugitive to apply to a United States district or circuit judge for a certificate to return his slave to the state from which he had fled. The law created a judicial process 
that must follow judicial rules. However, in 1793, many states contained only one district judge, and the circuit judges resided in only nine states. The limited number of judges required extensive travel and expense on the part of the owner before he came under the protection of the federal court system. The law further limited slaveowners since it neither authorized federal judges to issue warrants for the arrest of fugitive slaves, nor permitted slaveholders to demand aid from federal marshals in the pursuit of their fugitive property. Furthermore, over the next four decades, a few states passed personal liberty laws that made it more difficult for slaveowners to recapture their runaways. During that time, slaveowners claimed that northerners disrespected their property rights, harbored and employed fugitives, and manipulated state laws to impede their rights. Therefore, to further aid in the recovery of fugitives and to placate southerners, in 1842, in Prigg v. Pennsylvania the United States Supreme Court upheld the constitutionality of the Fugitive Slave Law of 1793. The Prigg decision also declared that enforcement of the law belonged to federal authorities and individual states did not need to provide means to carry out the provisions of the law. With this decision the Supreme Court backed Southerners in the recovery of their property. However, the long-term effects of the ruling disappointed many slaveowners as nine non-slave states followed a literal interpretation of Prigg and enacted laws between 1842 and 1850 that prohibited state officials from providing any type of assistance to federal agents including the use of jails and the formation of posses. As a result, on January 3, 1850, James Mason of Virginia introduced in the United States Senate a bill to provide aide to owners of runaway slaves "in securing them upon their capture in other States." During the same month, the Senate also heard bills to create governments in the land the United States acquired from Mexico 
in 1848. Proposals for the Mexican cession called for the Senate to admit California as a non-slave state and organize the rest of the area as the non-slave territory of New Mexico. Other proposals included a resolution to a border dispute between New Mexico and the slave state of Texas and to ban slavery in Washington D.C. ${ }^{1}$

The January 1850 proposals divided the Senate into four groups - two of which favored compromise and two did not. Pro-compromise Democrats favored an idea they called popular sovereignty. They argued that Congress should stay out of the controversy and let the areas decide the slavery issue for themselves. Pro-compromise Whigs did not favor popular sovereignty. They believed the Constitution provided Congress power over slavery in the territories; however, they favored some type of compromise on the proposals. Long-time statesmen Henry Clay of Kentucky and Daniel Webster of Massachusetts led the pro-compromise faction. Members of the anti-compromise FreeSoil party agreed that Congress controlled slavery in the territories and they believed that the Senate should use that authority to ban the spread of slavery. Until his death in April 1850, a third long-term statesman, John Calhoun of South Carolina, led the anticompromise Democrats. Anti-compromise Democrats held to the strict states' rights philosophy that the Constitution protected slaveholder's rights to take their slaves into the

$1 \quad$ H. Robert Baker, Prigg v. Pennsylvania: Slavery, the Supreme Court, and the Ambivalent Constitution (Lawrence: The University of Kansas Press, 2012), 65. See also, Paul Finkelman, Slavery in the Courtroom: An Annotated Bibliography of American Cases (Washington: Library of Congress, 1985), 60-64; James McPherson, Battle Cry of Freedom: The Civil War Era (New York: Ballantine Books, 1988), 79; David M. Potter, The Impending Crisis, 1848-1861 (New York: Harper \& Row, 1976), 139; Stanley Campbell, The Slave Catchers: Enforcement of the Fugitive Slave Law, 1850-1860 (Chapel Hill: The University of North Carolina Press, 1968), 8; The Congressional Globe, First Session, Thirty-first Congress, Volume 21, Part 1, 99. 
territories and bound the federal government to protect them. ${ }^{2}$ To further complicate the situation, Senators from Maryland, Virginia, Kentucky, and Missouri represented slave states that bordered on non-slave states and their constituents divided between strongUnion and strong-slavery sympathies. Senators of these border slave states feared a split within the boundaries of their states and leaned more toward compromise than their Deep South colleagues. Whig President Zachary Taylor muddied the waters even further. President Taylor demanded the immediate admission of California as a free state, supported the admission of New Mexico as a free state, and announced he would not sign any compromise measure. ${ }^{3}$ Three months of acrimonious debate occurred, which at times almost led to violence in Congress, after the introduction of the bills. Neither of Indiana's Senators, Jesse Bright nor James Whitcomb, spoke on the Senate floor during the springtime debates; however, both Senators supported the Fugitive Slave bill.

Jesse Bright resided in Madison. In 1845, the Indiana legislature elected Bright to the Senate and he soon built a strong political machine for himself. Bright controlled the Indiana Democratic Party and throughout the 1850s the party ran the state government. In 1854, when Vice-President William King died, the Senate elected Bright as its president, which put him next in line to be President of the United States. Despite the fact that Bright represented a non-slave state, he owned a large number of slaves that he kept on his land holdings in Carroll County, Kentucky. Carroll County borders the Ohio

2 Holman Hamilton, Prologue to Conflict: The Crisis and Compromise of 1850 (Lexington: The University of Kentucky Press, 1964), 25. John C. Waugh, On the Brink of Civil War: The Compromise of 1850 and How it Changed the Course of American History (Wilmington, Del.: Scholarly Resources, Inc., 2003), 8.

3 Craig R. Smith, The 1850 Compromise:A Study of Freedom of Expression in the United States Senate (Washington, D.C.: Freedom of Expression Foundation, 2001), 5. McPherson, Battle Cry of Freedom, 75. 
River and is about fifteen miles east of Madison. Indiana's junior Senator in 1850 was former-governor James Whitcomb. Whitcomb took his seat in the Senate for the first time days before the introduction of the Fugitive Slave Bill. Like Bright, Whitcomb was a Democrat, but he and Bright were too dissimilar in character or political methods to have much else in common. When Whitcomb arrived in the capital, he found Bright entrenched with their Senate colleagues. Poor health led Whitcomb to miss many sessions as well. As a result, unlike Bright, Whitcomb found himself with little influence. ${ }^{4}$

Despite his lack of influence, Whitcomb visited Senators Henry Foote of Mississippi, Lewis Cass of Michigan, and others, a few days after Mason introduced the Fugitive Slave Bill, to persuade them to bring the bill for a vote. He believed that the loss of fugitive slaves was the principal grievance of the people of the Southern states. Owners of slaves who lived in the border slave states complained louder than the deep South slave owners since their proximity to the non-slave states made it easier for their slaves to flee. ${ }^{5}$ Whitcomb convinced himself that a great majority of the people in the North supported justice for slaveowners. The Senators with whom he spoke suggested that it would not be courteous to Mason for Whitcomb to push the bill forward so Whitcomb met with Mason. Whitcomb related to Mason that with minor amendments, the bill would receive "the favorable regard of the great mass of the people of every section of our . . Union." ${ }^{6}$ However, Mason did not bring the bill for a vote and the

$4 \quad$ Charles H. Money, "The Fugitive Slave Law of 1850 in Indiana," Indiana Magazine of History 17 (June 1921), 164, 166.

5 Hamilton, Prologue to Conflict: The Crisis and Compromise of 1850, 22.

6 The Congressional Globe, First Session, Thirty-first Congress, Volume 21, Part II, 1574. 
debate continued until April. At that time Foote suggested a Senate committee to resolve the questions about fugitive slaves, slavery in the Mexican cession, the slave trade in Washington D.C., the admission of California, and the Texas-New Mexico border.

On April 18 Senators chose a thirteen-member committee to draft a solution to the issues. The committee consisted of three Northern Whigs, three Northern Democrats, three Southern Whigs, three Southern Democrats, and a chairman, Kentucky Whig Henry Clay. Bright was one of the Northern Democrats. Bright commented on his selection, "I might with great propriety, have declined this service ... but the public functionary who . .. declines responsibility, does less than his duty." The committee met for a week then Clay prepared the final document on April 25. "Having been honored with a place on the committee, I have in good faith used my humble efforts to aid others more capable of executing the implied duty assigned us," stated Bright. Clay presented the committee's recommendations to the full Senate on May 8. The committee incorporated most of the proposals into one comprehensive bill that earned the derogatory nickname of the Omnibus Bill since it was a vehicle on which any proposal could ride. Clay liked the nickname and it stuck. Clay recognized that the proposals demanded greater concessions from the North than from the slave states. The North had nothing tangible to lose since their objections to slavery were based on ideology while the Southern concerns were based on property. Clay appealed to the North to sustain the Union. In regard to fugitive slaves, the Omnibus bill created an administrative process for the return of runaways rather than a judicial process. The new procedure authorized United States commissioners to issue warrants for the arrest and certificates for the return of runaways. Commissioners could accept an affidavit by the accused fugitive's master as proof of 
ownership and could call bystanders with summonses to enforce the law. To circumvent personal liberty laws, marshals and deputies who refused to execute the warrants and citizens who prevented the arrest of accused runaways could be fined, arrested, and ordered to pay damages. Since the hearing was an administrative hearing not a judicial proceeding, the bill denied the right of trial by jury to fugitives who claimed to be free and their testimony could not be admitted as evidence in case of a hearing. The bill called for a fee of ten dollars for the commissioner if he returned the accused to slavery and five dollars if he released the accused. The commissioner could deputize private citizens to escort the slave out of the state if the claimant feared an attempt to rescue the slave by force. The cost for the deputies was to be paid by the United States government. The committee also included recommendations in the bill to settle all of the other issues. Critics of the bill argued two major points. First, the bill put the burden of proof of freedom on captured blacks but gave them no legal power to prove their freedom. Second, justified by the additional paperwork needed to remand a fugitive, the fee provided a bribe to commissioners. ${ }^{7}$

Bright made his first comments in the Senate on the issues the same day Clay introduced the committee's work. Although he did not discuss any individual piece of the proposal, Bright urged his fellow Senator's to pass the bill. "Several honorable Senators . .. have announced their dissent to certain arguments and conclusions contained in the

$7 \quad$ Robert Remini, At the Edge of the Precipice: Henry Clay and the Compromise that Saved the Union (New York: Basic Books, 2010), 122. The Congressional Globe, First Session, Thirty-first Congress, Volume 21, Part 1, 956. Appendix to the Congressional Globe, First Session, Thirty-first Congress, Volume 22, Part 1, 115-127. Waugh, On the Brink of Civil War, 183-184. Emma Lou Thornbrough, The Negro in Indiana (Indianapolis: Indiana Historical Bureau, 1957), 114. McPherson, Battle Cry of Freedom, 80. 
report," he stated. "That which is objectionable to one, is acceptable to others, and vice versa. ... [T] here are reasons and conclusions in the report in which I did not entirely concur, in committee, but, failing the consummation of my views there ... I now endorse it," he concluded. Bright reiterated his belief two months later when he made his only other public comment about the bill. "[I]f coming events cast their shadows," he stated, "none can doubt the passage of the measure; and if it does pass, I think I see in the future, what is so much desired by every well-wisher of this Republic - peace, quiet, and confidence restored the country over." ${ }^{8}$

Debate continued from May until August. One roadblock to the compromise disappeared when President Taylor died in July and the pro-compromise Millard Fillmore replaced him. However, when it voted in August the Senate rejected the Omnibus bill. The rejection marked the end of the Clay-Calhoun-Webster influence in national affairs. Democrats Stephen Douglas of Illinois and Jefferson Davis of Mississippi and Whig William Seward became the new leaders of the opposing ideologies. Davis pushed for states' rights; Seward fought for the immediate abolition of slavery; Douglas tried to find middle ground. Later in August, Douglas reintroduced the pieces of the proposal as six individual bills. On August 26, the Senate voted 27-12 to accept the Fugitive Slave Law. The other bills passed throughout August and September and President Fillmore signed them all. Both Bright and Whitcomb abstained from the Fugitive Slave Law although each had spoken in support of the bill. Bright voted in favor of the other five bills. He later stated the he was "accidentally absent" from the Senate chambers on the

$8 \quad$ The Congressional Globe, First Session, Thirty-first Congress, Volume 21, Part I, 956, The Congressional Globe, First Session, Thirty-first Congress, Volume 21, Part II, 1379. 
day of the vote but "I advocated those measures then, and ... uniformly gave them my support." The Madison Courier reported that Bright met with Evansville, Indiana Whigs "endeavoring to get a mail line established ... from Evansville to Louisville" on the day of the vote. Whitcomb's stated reason for missing the vote was health issues. Only four Senators voted for each of the six bills. Many Senators who favored parts of the proposals but not other parts paired with members who had opposite feelings so that each could miss votes and not have political ramifications back home. After the vote, one congressman suggested to "notify the members ... that the Fugitive Slave bill has been disposed of, and that they may now come back into the hall." Neither Bright nor Whitcomb suffered political backlash back home for their support of the bills. The Indiana legislature reelected Bright in the fall of 1850. Whitcomb died in October 1852 before his term was half expired. ${ }^{9}$

When the Fugitive Slave bill passed the Senate, it moved to the House of Representatives. Indiana's representation in 1850 encompassed eight democrats, a Whig, and a member of the Free Soil party. Eight of the ten were freshmen representatives. John Robinson, a Democrat, and Edward McGaughey, the Whig, were the only two Hoosier members who had served in the House of Representatives prior to 1850. Each of the parties in Indiana took a position against the extension of slavery; however, the majority of residents wished to maintain the Union even if it meant they must accept unpalatable provisions. State leaders and newspapers affirmed Indiana's devotion to the Union and the state's delegation to the House of Representatives reflected that devotion.

9 The Congressional Globe, Second Session, Thirty-first Congress, Volume 23, 492. The Congressional Globe First Session, Thirty-second Congress, Volume 25, Appendix, 1123-1124. Madison Courier 4 January 1851. Waugh, On the Brink of Civil War, 183. Money, "The Fugitive Slave Law of 1850 in Indiana," 166. 
In a speech in the House of Representatives, Ninth District Representative Graham Fitch attacked the proslavery forces in Congress for their aggressiveness and their threats of disunion over admitting California as a free state. However, the controversy in Congress that surrounded the package of compromise bills began to shatter the accord in Indiana on the non-extension of slavery. ${ }^{10}$

None of Indiana's ten representatives spoke about the fugitive bill in the House chamber. When it came to a vote on September 12, McGaughey, the Whig, and five Democrats - Brown, Nathaniel Albertson, Cyrus Dunham, Willis Gorman, and Joseph McDonald - voted for the bill. Three Democrats - Robinson, Fitch, and Andrew Harlan and Free Soil party member George Julian opposed it. In the next Congressional election in 1851 six members of the Indiana delegation lost their seats. Of the five Democrats who voted for the bill, the party did not re-nominate Albertson in the First District, Brown in the Fifth District, and McDonald of the Eighth District but Democrats retained each of those seats. The party set Brown aside for future governor and vice president Thomas A. Hendricks. Democrats re-nominated Dunham in the Second district and Gorman in the Sixth district and both won reelection. Of the three Democrats who opposed the bill, Robinson in the Third district and Fitch in the Ninth district each won reelection. However, the party did not re-nominate Harlan in the Tenth district, but retained the seat. Democrats also picked up the seat of McGaughey in the Seventh district. Many Whigs could not vote for McGaughey due to his support of the Fugitive Slave Act, and he lost to John Davis. The Whigs, however, gained Julian's seat from the

10 Emma Lou Thornbrough, Indiana in the Civil War Era: 1850-1880 (Indianapolis: Indiana Historical Bureau \& Indiana Historical Society, 1965), 3, 28, 45, 46. The Congressional Globe, First Session, Thirty-first Congress, Volume 21, Part I, Appendix, 138-140. 
Fourth district when free-soil Democrats who supported him in 1849 abandoned him in 1851. ${ }^{11}$ It is difficult to say with certainty that the Fugitive Slave Act played a role in the election of representatives in Indiana in 1851; however, it is unlikely. Democrats controlled eight of the ten seats before the bill passed. Five voted for the bill and three opposed. After the vote, Democrats held on to all eight of those seats and gained one more.

Democrats also made up the majority of the legislative delegation from the other two non-slave states that border Kentucky. Eleven Democrats, seven Whigs and three Free-Soil members represented Ohio in the House of Representatives, while Free-Soil Salmon Chase and Whig Thomas Ewing sat in the Senate. Unlike Indiana, the Ohio delegation did not favor the Fugitive Slave Act. Of the eleven Democrats, only two voted for the act while six voted against and three missed the vote. In addition, five of the Whigs and all three Free-Soil members voted against the act. One Whig supported the act and the seventh missed the vote. In the Senate, Chase voted against the Fugitive Slave Act and Ewing missed the vote. Both of the Illinois Senators, Stephen Douglas and James Shields, and six of the state's seven representatives belonged to the Democrat Party. Douglas and Shields both missed the vote, but five of the six Democrats in the House of Representatives supported the act. The other Democrat and the Whig voted against it. As in Indiana, it is difficult to say with certainty if the Fugitive Slave Act played a role in the reelection of representatives in Ohio and Illinois, but it is as unlikely as in Indiana. The Ohio legislature replaced Ewing with another Whig, Benjamin Wade. Democrats continued to hold eleven seats in the House of Representatives while

11 Money, "The Fugitive Slave Law of 1850 in Indiana," 167-168. 
Whigs won eight seats and the Free-Soil party controlled two. In Illinois, Democrats again won six of the seven seats.

Whether due to support of the Union, property rights, or racism, the majority of people throughout Indiana accepted the law. The presence of southern emigrants in the lower part of Indiana provided a social anchor for such sentiments. The law provided a concession to Southern slaveholders and sought to head off the secession of the slave states. Many public officials saw respect for the Fugitive Slave Act as an integral part of preserving the Union. In a speech to the Senate, Bright declared that the act was "supported by at least nine-tenths of the voters of Indiana." Reasons for the acceptance varied. According to Bright, Indiana voters "unite in repudiating disunionists south and abolitionists north." Back home Governor Joseph Wright also emphasized Indiana's devotion to the Union and the need for moderation. In December 1850 in his first message to the state legislature after Congress passed the law, Governor Wright sought to assure the South that Indiana would live up to its constitutional obligations. Wright deplored the ultraism and fanaticism that had been manifested by both sides on the debates preceding the compromise. "Indiana recognized the imperative duty," stated Wright, "of obedience to the laws of the land" and declared that "Indiana knows no North, no South, nothing but the Union." He added, "Indiana takes her stand in the ranks, not of Southern destiny, nor yet of NORTHERN DESTINY. She plants herself on the basis of the Constitution; and takes her stand in the ranks of AMERICAN DESTINY." ${ }^{12}$

12 Dean Kotlowski, "The Jordan is a Hard Road to Travel," International Social Science Review, 79 (Fall/Winter 2003): 72. The Congressional Globe First Session, Thirty-second Congress, Volume 25, Appendix, 1123-1124. Journal of the House of Representatives of the State of Indiana, 1850-1851, 39-42. 
After the state Democrats picked their candidates for the next election, the party tried to silence controversy over slavery and emphasized the finality of the Compromise. William Brown's newspaper announced it would not support any candidate for president who favored repeal of the Fugitive Slave Act. Governor Wright also announced that the state would not support anyone for any office who sought to reopen the issues settled by the Compromise. The Democrat state convention endorsed the finality of the Compromise and re-nominated Wright for governor and Ashbel Willard of Floyd County for lieutenant governor. Men from the southern half of the state rounded out the ticket. Democrats in the northern part of the state weakened their position with their 1849 endorsement of Free Soil principles. In 1852, Wright and the party won control of the state legislature by large margins and also controlled nine of the ten seats in the United States House of Representatives. ${ }^{13}$

Newspapers throughout the state also urged obedience to the law. Most of the papers asked that agitation cease and that the law be given a fair trial. Two competing Madison newspapers concurred with the prevailing sentiment and related evidence of harmony with the new law. The Whig controlled Madison Tribune stated, "The slave law may be radically wrong in principle, and justly obnoxious to public reprehension, and we do not say it is no, but so long as it has a place on the statute book, so long as it is the law of the land, it should be recognized as of binding force by all good citizens, and to counsel resistance to its operations, or incite to individual and organized opposition is hurtful in the extreme, tending only to anarchy and revolution." One of the Tribune's Madison competitors, the Democratic Weekly Courier concurred. "We don't, can't like it. It is repugnant to all the feelings of a man living in a free state," it editorialized. "We

13 Thornbrough, Indiana in the Civil War Era, 52-53. 
know ... this fugitive slave law ... makes the federal government a vast slave catching machine instead of leaving the enforcement of the law ... to the state officers. We don't like the law - probably never shall! We shall not, however, do anything by word or deed to nullify the law or prevent its being carried into force in Indiana." ${ }^{14}$

A small, vocal number of residents of Indiana remained who opposed the Compromise despite the calls for finality. The Fugitive Slave Law stood out to this minority as the most explosive part of the Compromise. Many people objected to the Fugitive Slave Law because they did not favor the extension of power it gave to the federal government at the expense of the states. Although the Fugitive Slave Act of 1793 gave slaveowners the right to recover their property, the new Fugitive Slave Act struck down laws that states created to protect their residents. The law placed federal commissioners in each county in the nation and gave them powers to issue arrest warrants, form posses, and even determine the status of alleged fugitives. Critics assailed the extra five dollar fee the commissioners received for a warrant as a travesty of just procedure. But most of those who opposed the law believed it threatened civil liberties for both races. An affidavit from a person who claimed ownership sufficed as evidence of ownership. The law further denied the alleged fugitives the right to testify in their own behalf. Since the law provided no statute of limitations, self-proclaimed slaveholders and their hired agents could enter a community, arrest any Black, claim that person as a slave, obtain certification of the claim by a United States commissioner, and then depart with their property. The law provoked further resentment with the provision of a fine and imprisonment for anyone who refused to assist in the arrest of a fugitive. Finally, some $14 \quad$ Emma Lou Thornbrough, "Indiana and Fugitive Slave Legislation," Indiana Magazine of History, Volume 50, 222. Madison Tribune, 19 April 1851. Madison Weekly Courier, 30 October 1850. 
Indiana residents found the law distasteful because it created a class of people who pursued fugitives for a living. These slave-catchers could now take advantage of the law and kidnap free blacks and sell them into slavery. ${ }^{15}$

In operation, the law intensified antislavery sentiment in the state in spite of the strength of the finality movement. Antislavery proponents not only protested the law as inhuman but also announced their intention of refusing to obey it. An eastern Indiana abolition convention in Wayne County passed a resolution that denounced the law as a bloodhound bill that outraged humanity and violated the plainest provisions of the Constitution. Residents of Fayette County declared they would not assist in the capture of fugitives even if the penalties for refusal would deprive them of their possessions and lead them to prison. An eastern Indiana newspaper called the law a mockery of justice and suggested the government issue licenses to kidnappers. ${ }^{16}$

Before the Fugitive Slave Act was two months old, man-hunters began to overrun some parts of Indiana and the state experienced its first fugitive trial at New Albany. In November 1850, the city's marshal, Jared Jocelyn, arrested a woman who appeared to be about fifty-five years old, her daughter, and the daughter's eight year old son. The marshal charged the three as fugitive slaves. Along with being Indiana's first fugitive slave case, circumstances made this case even more unique since the alleged slaves appeared to be white. According to the New Albany Weekly Ledger, "citizens exhibited a 15 Larry Gara, The Liberty Line: The Legend of the Underground Railroad (Lexington: University of Kentucky Press, 1961), 127; Kotlowski, "The Jordan is a Hard Road to Travel," 71; Paul Finkelman, Slavery and the Law (Madison, Wis.: Madison House Publishers, Inc., 1997), 145; Hamilton, Prologue to Conflict, 168-169. Darrel Bigham, On Jordan's Banks: Emancipation and its Aftermath in the Ohio River Valley (Lexington: University of Kentucky Press, 2006), 42; Col. William Cockrum, History of the Underground Railroad (New York: Negro University Press, 1915), 279.

16 Thornbrough, Indiana in the Civil War Era, 50. Thornbrough, "Indiana and Fugitive Slave Legislation," 222. Kotlowski, "The Jordan is a Hard Road to Travel," 71. 
good deal of feeling" over the arrest "not because of any general sympathy for fugitive slaves, but because they believe that persons of the Anglo-Saxon race had been unjustly deprived of their liberty." 17

The family moved to New Albany from Louisville during the summer of 1850. The boy attended school that fall with the white children of the city while his mother and grandmother worked. However, in late October, someone enticed the three across the Ohio River to Louisville under the pretense that they would receive money. That person kidnapped them and put them on a steamboat bound south. When the steamboat arrived at Hawesville, Kentucky, a mob of slaveholders, who believed the three were white, tore the alleged runaways from the kidnapper and threatened him with violence. Authorities took the fugitives before the proper tribunal once milder counsel prevailed. A local judge released them "on the ground of their being free from the stain of African blood." The family then made its way back to New Albany, where, according to the Daily Ledger, "there is no community in a free state less tainted with abolition sentiment." Upon their return, however, on November 11 a man from Arkansas by the name of Dennis Framell appeared before Marshal Jocelyn and asserted that the three were his fugitive slaves. Popular unrest among the citizens of New Albany translated into community action as lawyers stepped forth to defend the accused. Local physicians examined the defendants as well and pronounced no trace of "African" blood. ${ }^{18}$

During the hearing, the oldest woman said she originally lived in Baltimore. Indians killed her husband many years earlier and carried her and her daughter to

$17 \quad$ New Albany Weekly Ledger, 12 November 1850. New Albany Daily Ledger, 30 November 1850.

18 New Albany Daily Ledger, 12 November 1850, 15 November 1850, 27 November 1850. 
Arkansas as captives, but none of them had ever lived as slaves. However, Framell had no trouble in proving the three as his property, and Jocelyn, as the hearing officer, returned them to Framell. But before Framell received his property, someone appealed the case by a writ of habeas corpus to the United States District Court of Judge Elisha Huntington, thinking that by delay, evidence in the case might be obtained from the former Arkansas neighbors of the alleged fugitives. Huntington held the three in the New Albany jail to await the evidence. ${ }^{19}$

Huntington wanted to rule in favor of Framell, but he feared that such a ruling might stir citizens to free the defendants by force. However, Jocelyn, advised Huntington not to worry and to decide the case as he saw fit. Jocelyn knew of a community-wide campaign to purchase the freedom of the alleged fugitives and knew the citizens did not plan to rescue the family. The case interested prominent citizens of Louisville as well and several of them proposed to raise the necessary funds to gain the family's liberty. In the meantime, the people of New Albany held a meeting to raise money for their release. A committee of New Albany citizens met with Framell to negotiate a price as the legal proceedings began. He agreed to give the trio up for $\$ 600$ which the people of New Albany raised. On November 29, Huntington sent the United States marshal to deliver the family to Framell in Kentucky. The New Albany committee then met Framell in Louisville where he exchanged the family and a bill of sale for the six hundred dollars. ${ }^{20}$

Although citizens of New Albany disagreed with Huntington's decision, they supported the Union and the Fugitive Slave Act. For New Albanians, the matter proved 19 New Albany Daily Ledger, 27 November 1850, 30 November 1850. New Albany Weekly Ledger, 4 December 1850.

20 New Albany Daily Ledger, 30 November 1850. New Albany Weekly Ledger, 4 December 1850. Louisville Journal, quoted in New Albany Weekly Journal, 4 December 1850 . 
easy to decide; the accused fugitives were white, could not be slaves, and had to be released. The Daily Ledger stated, "We hope never to hear of another such a case as this. For persons pronounced white by nineteen-twentieths of all who see them to be carried away captive and held as slaves is something revolting to the feelings of every American citizen." No one suggested circumventing the law and the family was freed by legal means. Several months after the case, the Daily Ledger still supported the law and urged others to support it as well. "The New Albany Ledger has never expressed its disapproval of the fugitive slave law," it stated. "The most aggravated case that has yet occurred under this law, took place in this city; and the public sentiment here at the time would perhaps have justified us in denouncing it; but we refrained from doing so then, as we shall now." The Ledger concluded, "Rather than see the agitation resumed, we would prefer to let the law remain precisely as it is." ${ }^{21}$

The same single-mindedness shown by Judge Huntington to hand over alleged fugitives also appeared in the second fugitive case in Indiana - the Mitchum case. On February 15, 1851, George W. Mason of Owensboro, Kentucky, went to a "grog shop" several miles north of Madison. An elderly black man named Mitchum was in the shop. Mitchum lived in Vernon, about twenty miles north of Madison, with his wife and children. Mason accused Mitchum of being his runaway slave, Stephen, and secured his arrest. Since Mitchum had lived near Vernon for nineteen years, his arrest sparked a good deal of interest. Spectators congregated about the town's courthouse as legal proceedings got under way. The local justice of the peace, P.L. Basnett, granted Mitchum a hearing in response to the nearby crowds. ${ }^{22}$

$21 \quad$ New Albany Daily Ledger, quoted in Madison Weekly Courier, 1 March 1851. 22 North Vernon Times, quoted in Madison Weekly Courier, 1 March 1851. 
Three lawyers - a Colonel Andrews, Mr. Higgins, and Mr. Bundy - volunteered to defend Mitchum. They attempted to secure a writ of habeas corpus to secure the old man's release, but failed. Next, the attorneys argued that since the adoption of the Fugitive Slave Law, the justice of the peace had no jurisdiction to hear the case. This argument did not sit well with Basnett. He ruled that in the absence of a federal commissioner he held jurisdiction over the trial. The judge then listened to the claimant's evidence. The only evidence Mason produced was the testimony of a neighbor, Mr. Marks. Marks stated that "Stephen" did not open one eye as wide as the other. Other than that, he bore no distinguishing physical features. Marks was sure that the accused was Mason's escaped slave although he had not seen him in nineteen years. Marks also testified that Stephen had been a blacksmith during his years of servitude. A Vernon resident verified that two or three years earlier Mitchum had boasted that he "could do almost any kind of smith work." In their defense of Mitchum, his attornies produced as their sole evidence a certificate in relation to "free negroes coming into the State" from the Overseers of the Poor in Crawford County, Indiana. Their defense relied on two points - the great lapse of time since Mitchum's alleged escape and his lack of distinguishing marks. Mitchum's lawyers argued that Mason could not absolutely identify him as his slave due to these points. However, Basnett ruled that the evidence convinced him beyond a doubt that Mitchum was Stephen and awarded him to Mason. ${ }^{23}$

Citizens of Vernon accepted the decision. The Vernon Times, similar to the New Albany Ledger after the state's first fugitive case, also urged residents to follow the law. "We are happy to state, that no excitement tending towards mob law existed," concluded the Times, "and we think our Kentucky neighbors leave our town satisfied that how great $23 \quad$ Ibid. 
soever our abhorrence to the institution of slavery may be, still we are a law abiding people." ${ }^{24}$ The opposition to public disturbances and affirmation of the sanctity of property rights reported by the Ledger and Times echoed the sentiments of most residents of the state.

Simultaneous to the first two fugitive cases, delegates met in Indianapolis in the winter of 1850-1851 to write a new state constitution. Critics of the original constitution disliked the operation of the General Assembly, the election machinery, the lack of democracy in the judicial department, the abuse of power by the governor, and the administration of county government. Critics also advocated economic and social change. The social changes that many citizens of Indiana desired involved the status of Black residents. Southern states, including Kentucky, enacted stringent legislation against free Blacks prior to 1850 , which led many Blacks to migrate north of the Ohio River. Indiana residents looked at this migration as a threat to their civilization and regarded the solution as either amalgamation or exclusion. Delegate James Read of Clark County outlined three proposals during the convention to settle the threat. Read's first proposal was "amalgamation - aye, sir, I repeat it, amalgamation." Read's second suggestion called for the Blacks to take over the state. However, these two conclusions were unthinkable. As a result, Read suggested an idea that prohibited the further immigration of Blacks, as Illinois did in 1848, and to convince the Blacks who already resided in the state that they would never enjoy equal social or political privileges. According to Read, this plan saved the state for whites and their descendants. ${ }^{25}$

\footnotetext{
$24 \quad$ Ibid.

25 Donald Carmony, The Indiana Constitutional Convention of 1850-1851 (Indianapolis: The Indiana Supreme Court, 2009), 11, 15. Thornbrough, The Negro in Indiana, 64. Report of the Debates and Proceedings of the Convention for the Revision
} 
The strongest support for Read's exclusion proposal came from the southern section of the state. In 1850, Clark, Floyd, and Jefferson counties contained the fifth, sixth, and seventh largest Black populations in the state. The 1724 Blacks who lived in those three counties made up $15.3 \%$ of the state's total Black population. Clark County's 582 Blacks made up $3.7 \%$ of the county population. Blacks constituted $5 \%$ of Jeffersonville and 6\% of Charlestown, the two largest towns in Clark County. Floyd County's 574 Blacks made up 3.9\% of its population. Five percent of New Albany's population was Black. Jefferson County's overall population was larger than both Clark and Floyd County in 1850; however, slightly fewer Blacks, 568, lived there. Many of them lived in Madison. ${ }^{26}$ Prior to the convention, delegates from Floyd and Clark counties canvassed their districts and found near unanimous consent among their constituents that the state stop Black migration. ${ }^{27}$

Democrat Robert Dale Owen, who defended the rights of women and the working class at the utopian society of New Harmony that he created in southwestern Indiana, chaired the Committee on the Rights and Privileges of the Inhabitants of the State. Owen's committee presented a proposal in the first days of the Convention that mandated the first legislative session after the adoption of the new constitution to pass laws to prohibit Black settlement and prevent the acquisition of land by Blacks. Not only did the delegates want to prevent future immigration, during the discussion of the proposal, delegates decided to persuade the 11,262 Blacks who already resided in Indiana to leave.

of the Constitution of the State of Indiana, 1850, Vol. 1 (Indianapolis: A.H. Brown, 1850), 247.

26 Census data was obtained from Thornbrough, The Negro in Indiana, 45 and J. Blaine Hudson, Fugitive Slaves and the Underground Railroad in the Kentucky Borderland (Jefferson, North Carolina: McFarland \& Co., Inc., 2002), 25.

27 Report of the Debates and Proceedings of the Convention for the Revision of the Constitution of the State of Indiana, 1850, Vol. 1, 445. 
Bloomington Democrat William Foster wanted a provision in the constitution that either jailed any Black who moved into the state or farmed them out for six months to the highest bidder. Foster suggested that the state give the proceeds of the bidding to the Indiana Colonization Society to send any Black who wished to immigrate to Liberia. Since Illinois already restricted Blacks, Foster believed, "Unless we protect ourselves, the result will be, that Indiana will be the great refuge of all the worthless, the halt, the maimed, and the blind negroes that are to be found in the Southern States." He added, "We cannot therefore be charged with inhumanity in preventing our State from being overrun with these vermin." Whig delegate James Rariden concurred. Rariden believed that since Kentucky's constitution banned free Blacks and Illinois's constitution barred the immigration of free Blacks, Indiana would be inundated with "[b]roken-down negroes." Therefore, Rariden suggested the constitution give the legislature the power to sell or apprentice Blacks until "the amount of their wages should be sufficient to send them to Liberia." Floyd County Democrat Phineas Kent asked for the creation of a select committee of one from each congressional district to determine a plan to separate races in Indiana. The delegates agreed to a select committee of five Democrats and five Whigs. Seven weeks later the committee submitted a proposal with six sections to the convention and recommended their passage. ${ }^{28}$

Delegates approved five of the six sections of the proposal. By a vote of 91 to 40 the convention adopted Section 1, which banned further Black migration into the state. The vote did not follow party lines as twenty Democrats and twenty Whigs voted against

$28 \quad$ Journal of the Convention of the People of the State of Indiana to Amend the Constitution, (Indianapolis: Austin H. Brown, 1851), 32, 68, 138. Report of the Debates and Proceedings of the Convention for the Revision of the Constitution of the State of Indiana, 1850, Vol. 1, 449-451, 573-575 562. 
the proposal. However, the vote did follow geographic boundaries, as Democrat William McKee Dunn of Madison was the only delegate from the southern part of the state who voted against the ban. The other parts of the proposal that passed included Section 2, which voided contracts with Blacks who entered illegally and subjected whites that employed or encouraged illegal Blacks to remain in the state to a fine of $\$ 10$ to $\$ 500$. Section 2 passed 78 to 59. The third section provided that the money collected from the fines be used to colonize any Blacks who wanted to immigrate. Section 3 received the most support from the delegates as it passed 100 to 32. Delegates passed Section 5, which mandated the General Assembly to enact laws to carry out the provisions, without a roll call. Section 6 called for voters to approve the proposal as a separate item from the constitution. The delegation rejected only Section 4, which denied Blacks the right to own real estate. Delegates embedded this proposal as Article XIII of the new constitution. $^{29}$

Residents of Indiana voted on the constitution and Article XIII separately on August 4,1851 . The constitution passed by an overwhelming majority of 113,230 to 27,638. The exclusion article passed by an even wider majority, as 113,828 favored the ban and only 21,873 voted against it. In only four of Indiana's 91 counties did more voters reject the ban than favor it. Three of those four counties border Michigan. Residents of Clark County favored the ban by a 2197 to 95 vote, while Floyd County passed the article by a 1711 to 143 count. $^{30}$ Likewise, in 1848 Illinois produced a new

29 Journal of the Convention of the People of the State of Indiana to Amend the Constitution, 652, 751-762, 767-773, 776-777.

30 Gwendolyn J. Crenshaw "Bury Me in a Free Land”: The Abolitionist Movement in Indiana, 1816-1865 (Indianapolis: Indiana Historical Bureau, 1993), 34. Donald Carmony, Indiana, 1816-1850: The Pioneer Era (Indianapolis: Indiana Historical Bureau, 1998), 450. Thornbrough, The Negro in Indiana, 68. Kenneth Stampp lists the 
state constitution that banned Black immigration and voters approved the measure by a two to one margin. ${ }^{31}$

Under the authority of Indiana's new constitution, the General Assembly passed a law that required Blacks who resided in the state before November 1851 to register with their county clerk. The clerks provided certificates to any Black who produced witnesses to prove their right to reside in the state. However, authorities appear to have ignored this provision. In Clark County, where a large percent of the population desired limits on the Black population, only 74 of the 582 Blacks registered with the clerk. Authorities made no effort at enforcement of the law. Jefferson County prosecuted one case for violation of the immigration law. A Madison resident named Curzy brought a Black into the state after the adoption of Article XIII and provided him with a job and home. Although the lower court dismissed the case against Curzy, the Indiana Supreme Court reversed the ruling. The Illinois Supreme Court also upheld that state's ban, but authorities did not invoke the law there either. ${ }^{32}$

Many believed the new federal Fugitive Slave Law of 1850 and the new state constitution of 1851 would solve racial problems in Indiana. By the summer 1851, the public accepted the Fugitive Slave Law and after the 1852 elections, most residents accepted the compromise as a final settlement of the slavery question. The state legislature did not pass any legislation to nullify the law, and Indiana courts did not attempt to test the supremacy of national law. In 1852 state lawmakers provided the use

exclusion vote total as 109,967 in favor and 21,006 opposed in Indiana Politics During the Civil War (Bloomington: Indiana University Press, 1949), 9.

31 Leon F. Litwack, North of Slavery: The Negro in the Free States, 1790-1860 (Chicago: The University of Chicago Press, 1961), 71.

32 Thornbrough, The Negro in Indiana, 70. State v. Curzy 19 Kerr, 430 (1862). Litwack, North of Slavery, 71. 
of county jails for the safe keeping of fugitives from justice or labor. Judges in Indiana, for the most part, reasoned that masters were entitled to the return of runaway slaves. Resistance to the law remained rare among residents. Moreover, the state's small Black population began to level off after 1850. Between 1840 and 1850, the number of Blacks in Indiana grew by fifty-seven percent, but over the 1850s Black population in the state increased by one percent to a total of 11,428. A large part of the Black population continued to live in the southern border counties. The number of Blacks who lived in Floyd County increased by 183 during the 1850 s to a total of 757 in 1860 . However, the Black population of both Clark and Jefferson Counties decreased during the same period. Clark County lost 62 Black residents to drop to a total of 520, while Jefferson County's total dropped from 568 to $512 .^{33}$

Most residents of Indiana favored the return of fugitives in order to maintain positive relations with southern states and to prevent disruption of the Union. During the 1850s real fugitive slaves received little sympathy in Indiana, but communities resisted attempts to kidnap people who they knew to be free. When a longtime resident or a white person faced prosecution, such as Mitchum and the New Albany family, the citizens used legal means to defend them. In most cases, judges refused to release suspected runaways, and citizens respected their decisions. Indiana residents rarely resorted to extra-legal means to release alleged fugitives. Anti-slavery sentiments did not excite the majority of the people of the state. For the most part, Indiana residents, authorities, and judges

33 Campbell, The Slave Catchers, 90, 102. Thornbrough, "Indiana and Fugitive Slave Legislation," 221, 224-225. The Statutes of the State of Indiana Containing the Revised Statutes of 1852, Volume I, 412. Kotlowski, "The Jordan is a Hard Road to Travel,"75. Census data was obtained from Thornbrough, The Negro in Indiana, 45. 
enforced the Fugitive Slave Law without fanfare. Residents and the press paid little attention when an owner or federal marshals returned a fugitive without violence. ${ }^{34}$

By the 1850s most residents of Indiana asserted that the state was a "white man's country." State citizens repeated this argument to support the immigration ban and to justify colonization. Many argued as well that the writers of the Declaration of Independence and Constitution created a nation "by white men, for white men." Therefore, state citizens, also opposed the expansion of slavery into the territories. Although a small number of people wanted to limit slavery for moral reasons, most hoped to preserve the territories for white farmers. Other Indiana residents favored restrictions on Blacks due to their support for the Federal Union. Tension over the slavery question grew throughout the country in the years after the Mexican War ended in 1848. The people of Indiana wished to maintain harmonious relations with the slave states and believed the Fugitive Slave Act settled the issue. ${ }^{35}$

However, determination to prevent the recovery of escaped slaves began to spread. The Fugitive Slave Act provoked some people who refrained from acting either for or against fugitives in the past to help defeat the act that now required them to become slave-catchers. Authorities arrested Norris Day, a white resident of Madison, in February 1854 for aiding runaway slaves. Although the judge released Day, he fled the area in fear of mob violence as public opinion in southern counties still supported the right of masters to reclaim their property. ${ }^{36}$

$34 \quad$ Campbell, The Slave Catchers, 49, 79.

35 Thornbrough, The Negro in Indiana, 55, 63. Stampp, Indiana Politics During the Civil War, 9.

36 Wilbur Siebert, The Underground Railroad From Slavery to Freedom (New York: Russell \& Russell, 1898), 48. Thornbrough, The Negro on Indiana, 109. Louisville Courier 17 February 1854. 
Although small numbers of Indiana citizens began to aid runaways after the Fugitive Slave Act, most state residents judged abolitionists with contempt until Congress passed the Kansas-Nebraska Act on May 30, 1854. The Kansas-Nebraska Act overturned the Missouri Compromise of 1820, which banned slavery in most areas west of the Mississippi River. Many northerners considered the Missouri Compromise a sacred law. The Kansas-Nebraska Act lifted the ban on slavery and allowed residents of the area to determine the legality of slavery. Most residents of Indiana denounced the act as a betrayal and, therefore, no longer felt obliged to honor the Fugitive Slave Act. In spite of the discontent, Senators Jesse Bright and John Pettit, who replaced the deceased James Whitcomb, both favored the Kansas-Nebraska Act, as did eight of the state's ten Democrat members of the House of Representatives. ${ }^{37}$

One week before the Congressional vote on the bill, Indiana Democrats held their state convention. Bright controlled the convention and prepared to make KansasNebraska the test of loyalty to the party. Bright and his forces pushed aside all dissent and adopted resolutions that endorsed the Act and the administration of Franklin Pierce. The Bright faction then read out of the party anyone who did not support the platform. This included Michael Garber, owner of the Madison Courier and former Bright ally. The Democrats who opposed the Kansas-Nebraska bill declared the Act did not represent the will of the majority of state residents and worked to create a coalition with Free Soil supporters, former Whigs, and others who did not support Bright's tactics. This group created the People's Party and held rallies throughout the state and pledged to support only men who promised to restore the Missouri Compromise. Garber led the support for

37 Campbell, The Slave Catchers, 81. Thornbrough, Indiana in the Civil War Era, 55-56. 
the group in Jefferson County. The People's Party won decisive victories in the fall elections as they gained control of nine of the state's eleven seats in the House of Representatives. They also won all of the contested state offices and a wide majority of the state House of Representatives. Only the counties of the extreme south remained a stronghold for the regular Democrats. ${ }^{38}$

Two years later, in 1856 the Democrats remained committed to the KansasNebraska Act and Jesse Bright although violent events in Kansas undermined the principle of popular sovereignty that the Act endorsed. During the 1856 campaign, Democrats tried to counteract the effect of the events in Kansas with appeals to race prejudice. They charged that the People's Party endorsed abolitionists and amalgamationists who favored full social and political equality for blacks. The tactic worked. Democrats won all state offices, including new Governor Ashbel Willard, as well as six of the eleven Congressional districts. Democrat James Buchanan carried the state's presidential electors. As in 1854, the strongest support for the Democrats came from the southern half of the state. ${ }^{39}$

As a result of the Kansas-Nebraska Act, eight northern states including Ohio adopted a new series of personal liberty laws to protect their Black residents. However, Indiana and Illinois remained two of only five northern states that never enacted such laws. Despite the lack of personal liberty laws, the base for anti-slavery advocates broadened in Indiana. Historian Dean Kotlowski compares the state's reaction to the slavery controversy to a set of concentric circles. A small number of anti-slavery

38 William S. Garber, "Jesse D. Bright and Michael C. Garber," Indiana Magazine of History 18 (1932), 34. Stampp, Indiana Politics During the Civil War, 22. Thornbrough, Indiana in the Civil War Era, 57, 61, 62, 67. 39 Thornbrough, Indiana in the Civil War Era, 69, 75, 76. 
militants comprised the center of the circles. A large number of law-abiding citizens who resisted the prosecution of free people formed the second circle. The outer ring included everyone who supported the acts and wanted fugitives prosecuted. The majority of the people in the state favored enforcement of the Fugitive Slave Law over disunion. The state legislature did not attempt to nullify the federal slave laws nor did state courts attempt to test the authority of the laws. Because there was less hostility to enforcement of the law, the federal government had its greatest success in enforcing the Fugitive Slave Law in Indiana. But the growth of abolitionism after the Kansas-Nebraska Act, converted the state into an armed camp. Slave owners reported more frequent escapes through southeastern Indiana. The Ohio River cities of New Albany, Jeffersonville, and Madison, where free Blacks concentrated, became flashpoints. ${ }^{40}$

After the Kansas-Nebraska Act, southerners became more energetic than before in their search for their escaped slaves. The number of attempts by slave owners to reclaim their property as well as the prosecutions of those who facilitated escapes increased. The increase in captures led the small number of abolitionists to believe that the laws amounted to an invitation for slavecatchers to kidnap free Blacks. The most well known fugitive trial in Indiana involved the attempted kidnapping of Indianapolis resident John Freeman. A Missouri man named Pleasant Ellington and several witnesses accused Freeman of being a runaway. At great expense, Freeman proved his former Georgian owner freed him in the early 1840s. When Freeman sued Ellington for damages, the

$40 \quad$ Potter, The Impending Crisis, 139. Thornbrough, "Indiana and Fugitive Slave Legislation," 223, 224. Hamilton, Prologue to Conflict, 170. Kotlowski, "The Jordan is a Hard Road to Travel,"80. Campbell, The Slave Catchers, 87, 89, 90, 185. Keith Griffler, Front Line of Freedom: African Americans and the Forging of the Underground Railroad in the Ohio Valley (Lexington: The University of Kentucky Press, 2004), 7. Hudson, Fugitive Slaves and the Underground Railroad in the Kentucky Borderland, 82. 
accuser fled Missouri. In June 1854, Southern Indiana residents stopped two other kidnappings. In Jeffersonville, a free black named James Cotes went to the train station where a kidnapper beat him over the head, cut him with a knife, and then bound him. The kidnapper took Cotes to Louisville, but a steamboat captain recognized the victim and gained his release. During the same month, a Kentuckian enticed a young Black male to go with him to the train station north of Madison. However, a crowd of people gathered at the depot and forced the man to release the child. ${ }^{41}$

Along with the use of kidnapping free Blacks, many times slave catchers did not bother to take captured fugitives to the proper authorities, but returned them south by the quickest route. Federal officials held only one fugitive case in each of the three southeastern counties of Jefferson, Clark, and Floyd after the 1854 Kansas-Nebraska Act. In July 1854, Madison authorities arrested a man on the steamboat Alvin Adams. A federal judge found him guilty of escape and turned him over to John Page of Bowling Green, Kentucky, who claimed him as his slave. In Clark County, federal officials returned John Tatson to his owner in February 1857. The only federal Fugitive Slave trial in Floyd County ended in April 1860 with the return of Tom Bishop to his owner. ${ }^{42}$

Despite the lack of trials, several incidents occurred in each county during the six years that followed the Kansas-Nebraska Act. These incidents reflect the growth in abolition activity in southeast Indiana. Slave-catchers in Jefferson County captured and

$41 \quad$ Siebert, The Underground Railroad from Slavery to Freedom, 240, 316. McPherson, Battle Cry of Freedom, 78. Money, "The Fugitive Slave Law of 1850 in Indiana," 180-198. American Anti-Slavery Society, The Fugitive Slave Law and its Victims: Antislavery Tracts No. 18 (New York: American Anti-Slavery Society, 1856), 28-29.

42 McPherson, Battle Cry of Freedom, 78. American Anti-Slavery Society, The Fugitive Slave Law and its Victims, 29, Stampp, Indiana Politics During the Civil War, 204, 206. 
returned fugitives on at least five occasions after the Kansas-Nebraska Act. In August 1854 a free Black man from Carrollton, Kentucky led two slaves on a skiff towards Madison. Slave-catchers apprehended the runaways, but their guide escaped. A month later, eighteen bounty hunters from Madison captured four Kentucky fugitives and returned them to their owners. The following year, in August 1855, two slaves fled attack dogs on their escape from Kentucky. Once in Madison, the fugitives requested aid from the conductor of the Madison and Indianapolis Railroad. However, the conductor reversed course and returned the slaves to their owner. After the return, in a display of disgust with the enforcement of the Fugitive Slave Law, Madison Courier editor Michael Garber stated, "After reaching Indiana - the free state of Indiana, which we teach our children in the Sunday Schools, and in the common schools, is the home of the oppressed, where the benefit of the laws and institutions are offered to men of every clime - they were arrested." Garber concluded by stating, "It is to be seen whether (the owners of the railroad) are willing to have it converted into a vast slave-catching machine.” In the fourth incident, a fugitive severely wounded Madison resident Caleb McQuithey during a capture in a valley outside of the city limits in September 1856. After McQuithey's colleagues returned the fugitive, Garber asked, "If McQuithey dies, will the negro be brought back for trial for the killing under the laws of the State of Indiana?" In the final reported capture in Jefferson County in September 1857, two white men aided the escape of four slaves from Louisville. A third white man took the group to Hanover, where a posse overtook the fugitives and returned them to their owners. ${ }^{43}$

$43 \quad$ Louisville Courier 24 August 1854, 14 September 1857. Madison Courier 27 September 1854, 3 September 1855, 25 September 1856. 
Madison's slave catchers did not always capture their intended target, however, as the local press recorded at least three parties of fugitives who eluded the bounty hunters of Jefferson County after 1854. In May 1855, five slaves used a stolen skiff to cross the Ohio River near Madison. Although the slaves escaped, authorities of Carrollton arrested a free Black named Edmund Prince for his assistance in the escape. However, Mexican War hero and Carrollton resident General William Butler interceded on Prince's behalf and gained his release. The following summer, in July 1856, two slaves arrived in Madison. Three city residents escorted them to Dupont, where a party of seven men captured the two fugitives. The three rescuers then recruited a larger force in Dupont to again liberate the runaways. The owner of the slaves arrived in Dupont a short while later, only to find his property gone. According to the Madison Courier, the owner "swore terribly" to no avail. A third successful escape through Jefferson County occurred in 1857. Dick Daily, a Carroll County slave, regularly traveled to Madison for his owner to carry produce. Daily's owner allowed him to go to Madison at will since he always returned faithfully. Daily used his owner's generosity to gather his family from a neighboring farm and flee. ${ }^{44}$

Fugitive activity increased in Floyd County after 1854 as well although many runaways encountered the same opposition as in Jefferson County. Slaves often attempted to use public transportation to get through New Albany. In February 1856, a white man named Elisha Hillyer and a veiled woman crossed from Louisville to New Albany on a ferry. At one point during the crossing, Hillyer lifted the woman's veil and kissed her. The ferry master realized the woman was Black and alerted authorities, who $44 \quad$ Louisville Courier 29 May 1855. Madison Courier 28 July 1856. Marion B. Lucas, A History of Blacks in Kentucky: Volume 1 From Slavery to Freedom, 1760-1891 (Frankfort: The Kentucky Historical Society, 1992, 64. 
then questioned her. The woman admitted to being a slave and officers returned her to her owner. Hillyer escaped, but authorities later found him hiding in a nearby cellar. In a separate incident, officers arrested another public transportation operator. Officers arrested William Hosea, the driver of the New Albany omnibus, on suspicion of using the vehicle to aid fugitives. However, the court released Hosea, since no one could prove he aided in any specific escape. Over the next few years, New Albany's largest newspaper, the daily Ledger, reported many other slave captures and returns without trials. On May 14, 1855, a night watchman captured a slave family in Louisville as they waited for a skiff to arrive from New Albany. The watchman saw the skiff cross the river, but the occupant of the skiff became alarmed and fled before anyone could catch him. Later that summer, officers captured a slave woman and returned her to a Mr. Dixon of Louisville. Another slave woman escaped to New Albany in 1856 and hid among the free Blacks in the West Union area of the city. She passed herself off as a free woman and married a West Union resident. However, several months later her former master happened to pass the home of a Black family in New Albany and by chance saw his former slave. The next day he came back to New Albany and reclaimed her. The residents of West Union became alarmed since the owner reclaimed her without a warrant and authorities allowed him to take her back to Kentucky without a trial. ${ }^{45}$

As in Jefferson County, successful escapes through Floyd County often became publicized, most often in the Louisville newspapers since John Norman, editor of the New Albany Daily Ledger, held an anti-black bias. Unlike Garber in the Madison Courier, Norman often wrote against Republicans, the anti-slavery movement, and of the $45 \quad$ New Albany Daily Ledger 15 May 1855, 28 August 1855, 20 February 1856, 9 December 1856. Pamela Peters, The Underground Railroad in Floyd County, Indiana (Jefferson, North Carolina: McFarland and Co, Inc., 2001), 9. 
infractions committed by Black citizens. Norman printed small infractions committed by Blacks that appeared in the police reports to incite the whites of Floyd County. He seldom wrote about successful slave escapes, but the Louisville Courier printed multiple stories of escapes through New Albany in order to show the need for the Fugitive Slave Law. In September 1855 the Louisville Courier reported a fugitive reached the cars of the New Albany and Salem Railroad. When New Albany officers attempted to arrest the runaway, the railroad conductor, James Hines, prevented the officers from entering the cars by force. The trains left New Albany with the fugitive on board. Railroad officials released a statement in response to angry protests by residents of Louisville. The statement assured Kentuckians that "employees of the N.A. \& S.R. will not be permitted to aid runaway negroes." The statement continued, "We know there are plenty of nigger stealers about New Albany" and "[n]o one will be more rejoiced than ourself to hear that the N.A \& S.R. has relieved itself from all suspicion." Due to the increase of runaways and slave catchers in the city, by the late-1850s white residents of New Albany created a vigilance committee to enforce state laws against Blacks. In the summer of 1860, Black leaders denounced the vigilance committees and urged Blacks to stand up for themselves. As a result, a mob of whites arrived at a black dance and chased the Blacks through the city. The New Albany Ledger chastised the Black leaders. City officials later ordered the enforcement of Article XIII of the constitution. Some of the expelled Blacks fled to Jeffersonville, but whites there drove them away as well. ${ }^{46}$

Abolition activity increased in Clark County after 1854 as well. A Louisville resident saw five Blacks cross the river into Jeffersonville late one night. Other witnesses $46 \quad$ Peters, The Underground Railroad in Floyd County, Indiana, 17. Louisville Courier 10 September 1855, 13 September 1855. New Albany Daily Ledger 14 August 1860. 
reported two unknown white men in the vicinity of C.Q. Armstrong's residence and believed the two whites aided the escape of the five Blacks. Armstrong offered a $\$ 500$ reward for the capture of the slaves or kidnappers. Later, two slaves who belonged to a Mr. Thompson of Louisville escaped with the help of a Black Jeffersonville resident named John Knight. Authorities arrested Knight in Jeffersonville in the fall of 1857 . The following year, in September 1858, two Black men crossed from Louisville on the Jeffersonville ferry. One of the men, a known free Black named Miles Wilson, paid the fare for both. The ferry collector became suspicious and arrested the men and returned them to Louisville. The second man admitted that he was the slave of F.A. Moore, but that the two only crossed the river to attend a dance and planned to return to Kentucky later that evening. A federal court indicted Wilson for aiding a runaway and sentenced him to ten years in prison. Wilson confessed to the act at his sentencing, but stated that a white storeowner in Jeffersonville named John Lancisco devised the plan. Escape routes in Clark County also led through Clarksville, Utica, and Charlestown. ${ }^{47}$

Anti-black sentiment increased in Indiana during the 1830s and 1840s and culminated with the new state constitution in early 1851 that excluded Black immigration into Indiana and encouraged those who already resided there to move to Liberia. However, residents believed the federal Fugitive Slave Act of 1850 forced them to become slave catchers and the Kansas-Nebraska Act of 1854 had the potential to close the territory to free labor. Passed by the Democrat led Congress, these two laws led more residents of Indiana to realize that the government's attempts to appease slave owners came at their expense. In the early 1860s as the Civil War began, Indiana turned away $47 \quad$ Louisville Courier 15 September 1858, 16 September 1858, 13 January 1859, 21 January 1859. New Albany Daily Ledger 12 October 1857. Peters, The Underground Railroad in Floyd County, Indiana, 87. 
from the Democrat party. In the presidential election of 1860, the Republican candidate, Abraham Lincoln, carried the state. In 1862, voters elected six Republicans, as opposed to one Democrat, to the House of Representatives. Members of the Senate expelled the slave-owning Jesse Bright and the Indiana legislature replaced him with pro-Union Democrat Joseph Wright. Republican Henry Lane held the other seat. In 1864 Republicans gained control of the state legislature. After the Civil War, state legislators repealed the limitations on Black residents. Although it took many years for racial attitudes to change, the Indiana legislature's concern for the status of Blacks resembled that of Jonathon Jennings and the state's earliest lawmakers. 


\section{CHAPTER 4}

\section{HISTORIOGRAPHY}

Blacks resided in the territory north of the Ohio River before the British ceded the area to the United States in 1783. United States laws and Indiana laws each affected Blacks after the cession. Chapter four of this thesis analyzes how historians described the treatment of Blacks in Indiana as well as the passage of laws and how laws affected the state's Black residents. The chapter divides the works into four sections. The first section discusses the general Indiana state histories that described the increase in Black population in relation to the early development of the state as a whole. The second section explores the works of historians who studied the specific development of Blacks in Indiana. Section three analyzes several monographs of the Compromise of 1850 and the Fugitive Slave Act that the Compromise created. Due to the Fugitive Slave Act, reports of illegal aid to fugitive slaves increased within the state. The final section examines historians who wrote about the illegal aid. This chapter argues that scholars have given some attention to this topic; however, much more work is needed.

Many pre-1850 general histories of Indiana provided brief descriptions of the treatment of Blacks in the early development of the state. In 1915, Logan Esarey wrote one of the first scholarly histories of Indiana when he produced A History of Indiana from 
its Exploration to 1850 for the state's one-hundredth anniversary. ${ }^{1}$ The first nine chapters of the book covered the period before statehood and began with a discussion of the small French settlement of the area. Esarey depended on the writings of the French Jesuit priests in his analysis of this period. The chapters that followed the French period included the English control after 1763, the conquest by Virginia during the Revolutionary War, and the Indian wars of the 1790s. According to Esarey, each of the periods shaped the political development of the Northwest Territory between 1785 and 1800, and the Indiana Territory from 1800 until the transition to statehood in 1816 . Once Indiana gained statehood, Esarey focused more on the economic development of the state through internal improvements. Esarey used newspaper editorials to describe the motives for those who supported the internal improvements rather than to confine his research to acts passed by the legislature. The book included a collection of maps that illustrated the development of the state. Although Esarey presented the political and economic growth of early Indiana, A History of Indiana from its Exploration to 1850 lacks an in-depth discussion of the social and cultural development of the state. The roles of women, Blacks, natives, religion, and education received limited treatment.

Fifty years after Esarey's state history, in the 1960s, the Indiana Historical Society commissioned a five-volume history of Indiana to celebrate the $150^{\text {th }}$ anniversary of the state's admission to the Union. The volumes trickled out over a thirty-year period. John D. Barnhart began the first volume, Indiana to 1816: The Colonial Period. ${ }^{2}$ After Barnhart's death, Dorothy L. Riker completed the work and emphasized political,

1 Logan Esarey, A History of Indiana from its Exploration to 1850, Vol. 1 (Indianapolis: Hoosier Heritage Press, 1915).

$2 \quad$ John D. Barnhart and Dorothy L. Riker, Indiana to 1816: The Colonial Period (Indianapolis: Indiana Historical Society, 1971). 
diplomatic, and military history. More than half of the book is devoted to the French and British periods and evaluated the international rivalries and conflicts with the natives. The second half of the book discussed territorial politics and the economic hardships of pioneer life. In considerable detail, Barnhart and Riker discussed the introduction of Blacks as indentured servants by Governor William Henry Harrison and the territorial legislature as well as their attempt to install slavery into Indiana. However, Indiana to 1816 lacks a discussion of the decline for the support of Harrison in territorial politics. A more complete evaluation of the success of the anti-Harrison political faction could explain racial attitudes of Indiana's early settlers.

In volume two of the state history, Indiana 1816-1850: The Pioneer Era, Donald Carmony used a variety of official government records, published letters and contemporary newspapers to emphasize political, economic, and constitutional history during the first decades of Indiana statehood. ${ }^{3}$ Over-speculation in canal building and the nationwide panic of 1819 created oppressive debt for the infant state. Carmony outlined the legislature's public finance policy to explain how the state survived its early financial crisis. He further explained that the delegates to the 1816 state constitutional convention faltered in their responsibility to create public schools as ordered by the Northwest Ordinance. Delegates referred school funding to a future general assembly rather than decide the issue themselves. As a result, Indiana children lacked adequate school facilities until the 1840s. Carmony's neglect of social topics is a major flaw of the book. Although Robert Dale Owen created the Utopian community at New Harmony during the time period covered in the book, Carmony provided no analysis of the experiment.

3 Donald Carmony, Indiana 1816-1850: The Pioneer Era (Indianapolis: Indiana Historical Society, 1998). 
Worse, he failed to mention the dramatic increase in German and Irish immigration of the 1840s as well as the effect on the state of religious revivalism. He discussed the roles of women and Blacks only when political developments affected them.

Emma Lou Thornbrough devoted one section of volume three of the state history to the 1850s and one section to the post-Civil War era. The early chapters of Indiana in the Civil War Era, 1850-1880 covered the pre-war political transition of Indiana from a Democratic to a Republican stronghold. ${ }^{4}$ Although the Senate expelled Indiana Democratic Senator Jesse Bright for disloyalty once the Civil War started and many residents of the state had family ties to the South, Thornbrough believed that previous histories exaggerated the amount of disloyalty among Indiana residents in the pre-war years. "Those who wanted to see the Union permanently divided ... were few," she stated. ${ }^{5}$ Unlike many historians who neglected Indiana post-Civil War politics, Thornbrough stressed the electoral importance of the state during the late nineteenth century as she noted that one president and two vice-presidents came from Indiana. Thornbrough also believed that few historians dealt with economic and cultural changes in the state; therefore, she highlighted transportation, agricultural, and industrial advances in the period, as well as race relations.

Volumes four and five of the state history fall outside the time period of this thesis; however, other histories of Indiana discussed the pre-1860 influence of race in the state. According to Kenneth Stampp in Indiana Politics During the Civil War, the sharp controversies in Indiana during the war were based on economic issues and were not a

$4 \quad$ Emma Lou Thornbrough, Indiana in the Civil War Era: 1850-1880 (Indianapolis: Indiana Historical Bureau \& Indiana Historical Society, 1965).

Ibid., 181. 
question of disloyalty. ${ }^{6}$ Stampp covered the period from the political campaign of 1860 to the end of the Civil War and explained the eventual triumph of the Republican Party in the state. He argued that economic issues throughout Indiana aligned Jacksonian Democrats against the principles of Henry Clay as exhibited in the Republican dominated Union Party. Democrats were not pro-South; rather, they opposed the tariff and other Whiggish policies of the Republican/Union Party. Stampp stressed that historians labeled Democrats of southern Indiana as disloyal. He argued that although state residents were involved in strong partisan politics, all were conservative when faced with political or economic radicalism. According to Stampp, the Democratic victory in the state elections of 1862 was a repudiation of radical Republicanism not a repudiation of the Union. Based on official documents, personal memoirs, letters and Indianapolis newspapers, Stampp analyzed the history of Indiana politics in greater detail than the influence of economic developments.

Other than her general history of the state, Emma Lou Thornbrough wrote of the specific roles of Blacks in Indiana. Written in 1957 during the early years of the United States Civil Rights movement, in The Negro in Indiana: A Study of a Minority Thornbrough used newspapers, court records, census data, legislative documents, minutes of Quaker meetings and other church conferences to explore the legal, economic, and social patterns of Blacks that lived in Indiana prior to $1900{ }^{7}$ Thornbrough not only examined Black life and activities in Indiana, but also studied white Indiana's struggle to define its relationship to Blacks. She divided the volume into two chronological periods

$6 \quad$ Kenneth Stampp, Indiana Politics During the Civil War (Bloomington: Indiana University Press, 1949).

7 Emma Lou Thornbrough, The Negro in Indiana (Indianapolis: Indiana Historical Bureau, 1957). 
of before 1860 and after 1865 and focused on education, population, and political events. In the first half of the study Thornbrough described involuntary indentured service before statehood; the slow growth of Black population and white efforts to stop immigration; the colonization movement; dangers to personal liberty, including kidnapping, slave catching and discrimination; and religion and education. Throughout The Negro in Indiana, Thornbough focused on legalized repression and suggested that whites viewed Blacks as aliens and sought to "preserve the soil for white men." She concluded that Blacks were not victims of whites but they were economically weak and their opportunities limited. However, Thornbrough neither compared the racial atmosphere in Indiana to the rest of the United States nor provided analysis of white migration into the state. Discussion of white population movement could provide insight into Indiana's racial attitudes.

Thornbrough also wrote "Indiana and Fugitive Slave Legislation" for the Indiana Magazine of History in 1954. In the article, Thornbrough studied the fugitive slave relationship between Indiana and Kentucky. ${ }^{9}$ Thornbrough analyzed the animosity that developed after Indiana became a state to examine how the fugitive question created conflicts about the authorities of national and state governments as well as to examine the problems of interstate relations. Since the Fugitive Act of 1793 did not protect free Blacks from illegal seizure and enslavement, in 1810 and again in 1816 Indiana legislators passed anti-kidnapping laws. However, many residents of the state and of Kentucky argued that both of Indiana's anti-kidnapping laws conflicted with the Federal law of 1793. Thornbrough used newspaper accounts and court records to describe three kidnapping trials against Kentucky residents in Indiana between 1818 and 1824 and the

\footnotetext{
$8 \quad$ Ibid., vii.

$9 \quad$ Emma Lou Thornbrough, "Indiana and Fugitive Slave Legislation," Indiana Magazine of History (1954): 201-228.
} 
animosity the trials created between the governments of the two states. In a display of concern for the state's Black residents, the Indiana legislature defended its right to pass the kidnapping laws and declared the laws constitutional. However, Thornbrough argued that due to protests from the Kentucky governor and legislature, in 1824 the Indiana assembly made pronounced concessions to the demands of slaveholders. Thornbrough studied Indiana's legislative acts and concluded that between 1824 and 1850, the state government desired to placate slave states rather than protect the rights of residents claimed as fugitive slaves. Although many other non-slave states passed personal liberty laws in the 1840s to protect their Black residents, the Indiana legislature and courts placed the preservation of national unity above the rights of fugitive slaves or free Blacks.

Other historians compared the development of Blacks in Indiana to blacks in other areas. In On Jordan's Banks: Emancipation and Its Aftermath in the Ohio River Valley, Darrell Bigham explored life for African Americans in fifty counties that border the Ohio River. ${ }^{10}$ Bigham compared the social, political, and economic life of the Blacks who lived in the twenty-five Kentucky counties on the south side of the river with the lives of the blacks who lived in the twenty-five counties in Illinois, Indiana, and Ohio that are across from Kentucky. Bigham argued that with the exception of urban areas, due to slavery the south-bank counties developed separately despite the fact that their northbank neighbors were linked by geography and demography to the south. He further argued that the separate development persisted after the Civil War.

$10 \quad$ Darrel Bigham, On Jordan's Banks: Emancipation and its Aftermath in the Ohio River Valley (Lexington: University of Kentucky Press, 2006). 
Bigham divided On Jordan's Banks into three sections. In the first, he discussed the development of the Ohio River valley from the time of Kentucky's admission as a state until the beginning of the Civil War. Before the war, the majority of Blacks who lived in Ohio River counties lived in rural areas of Kentucky where the desire to maintain white supremacy led to hostility against Blacks. Not only did slaves face the threat of physical abuse and forced separation from their families, but educational opportunities were nonexistent as well. Although north-bank Blacks had more opportunities, they faced racism and hostility from whites on a daily basis. Whites limited north-bank blacks in their occupations, housing, educational opportunities, and other rights. However, whites tolerated Blacks as long as blacks remained in their own physical or cultural area. In the second section of the book Bigham described the impact the Civil War had on the valley's Black population. Bigham calculated that 49,075 slaves lived in Kentucky's twenty-five Ohio River counties. During the war many of those slaves ran away. In the 1860 census the population of the twenty-five north-bank counties was 12,513 . The most dramatic effect of the war on those counties was the increase in the number of Black residents. Bigham devoted most of the book to the third section and the post-war years. In Kentucky whites used violence against their former slaves to keep the status quo. The violence and search for employment led many Blacks to migrate north, which worsened the racial relations in the north-bank counties.

Bigham alternated chapters between Kentucky and the north-bank counties, however the book contained one map and most of the counties were not identified. Readers who lack the geographical knowledge of the valley will be confused. In addition, the statistical detail of his data too often overshadowed the narrative. Bigham's 
use of tax records, local newspapers, and census records provided insight into the social aspects of rural black community development. Bigham showed that Blacks lived separate from whites, whether by law, custom, or fear, and that they survived this separateness by forming their own social organizations.

Joe William Trotter expanded the comparison from the counties that border the Ohio River at Kentucky to include the rest of the river valley. In River Jordan: African American Urban Life in the Ohio Valley, Trotter analyzed Black life in four Ohio River Valley cities - Pittsburgh, Cincinnati, Louisville, and Evansville, Indiana - to document the role of Black workers, Black urban life during the rise of capitalism, and the emergence of a Black middle class. ${ }^{11}$ Trotter divided the study into three time periods expansion of commercial capitalism (1790-1881), emancipation, race, and industrialism (1861-1914), and the industrial age (1914-1945) - and highlighted the similarities and differences in social history of the four cities. However, the use of Evansville appeared out of place since its economic and population growth lagged far behind that of the other cities. Trotter used secondary sources to conclude the rise in racism resulted from the changes and growth experienced by each city and argued that racism increased with the increase of German and Irish immigration.

The treatment and development of Blacks in Indiana resulted from both federal and state laws. Perhaps the most important legislative action that affected Blacks in Indiana was the Compromise of 1850, in particular the Fugitive Slave Act that the Compromise created. Historians have analyzed the Compromise in various ways. In Prologue to Conflict: The Crisis and Compromise of 1850, contrary to earlier historians,

\footnotetext{
11 Joe William Trotter, River Jordan: African American Urban Life in the Ohio Valley (Lexington: University of Kentucky Press, 1998).
} 
Holman Hamilton concluded the House of Representatives, the presidents, and lobbyists played as vital a role as the Senate in the passage of the Compromise. ${ }^{12}$ He also argued that the actions of Democrats were more effective than the actions of Whigs. Unlike most historians who explained that the extension of slavery into the territories acquired from Mexico caused the crisis of 1850, Hamilton argued that no single issue led to sectional conflict in the decade before 1850 . He studied the debates and committee reports of the Thirty-first Congress, as well as United States Treasury records, newspapers, and manuscript collections and concluded that several issues, including the Texas debt issue, led to the rift. Hamilton began his study with a description of President Zachary Taylor's push to add California and New Mexico as non-slave states and with the Texas-New Mexico border dispute. Since Congress decided statehood applications and border disputes, Hamilton next described the men and the factions of the Senate as well as the chaos that surrounded the election of the Speaker of the House of Representatives. He discussed the introduction of several slave and Texas-debt related bills into each house of Congress. Hamilton explained that the combination of the Congressional factions and the bills led Henry Clay to introduce the Omnibus bill in February, and followed with a description of the debate that surrounded Clay's proposal. Hamilton provided his most detailed analysis when he examined the votes of each Senator on each ballot of the July 31 vote that defeated the Omnibus bill. He theorized that neither sectionalism nor partisanship accounted for the results, but a partisansectional combination defeated the bill. He ended with an explanation of the role of Stephen Douglas in the eventual success of the individual parts of the Compromise.

12 Holman Hamilton, Prologue to Conflict: The Crisis and Compromise of 1850 (Lexington: The University of Kentucky Press, 1964), 25. 
Hamilton tied Douglas and other legislators to Texas bond lobbyist William Corcoran, who gained $\$ 600,000$ when the United States assumed the Texas debt. Hamilton concluded that "Corcoran was the principal sponsor, initiator, or guiding spirit in countless phases of politico-financial enterprise connected with the compromise and compromisers."13 Despite his implication, Hamilton did not provide evidence to show that any Congressman received bond money or that the prospect of bond money caused any Congressman to change his vote.

Similar to Hamilton, Robert Remini argued that more than one issue divided the United States in 1850 and the combination of those issues led to the Compromise. In At the Edge of the Precipice: Henry Clay and the Compromise that Saved the Union Remini stated that the origins of the crisis began in 1803 when Thomas Jefferson purchased the Louisiana Territory. ${ }^{14}$ When the question of slavery in the territory disrupted the House of Representatives in 1820, Speaker of the House Clay created the Missouri Compromise of 1820 that settled the issue. The next issue that divided the United States concerned the 1828 tariff. Remini outlined South Carolina's objection to the tariff and President Andrew Jackson's threat to use force against South Carolina. Clay worked with both sides to produce a compromise and ended the threat of secession and civil war. The crisis of 1850 began when prospectors rushed to the California gold mines in 1849. Remini stated that President Zachary Taylor's plan to admit California as a non-slave state was unworkable for two reasons. First, California, New Mexico, and the Mormon territory of Deseret would all apply for admission as non-slave states, a situation the slave states would never allow, and second, Taylor ignored the Texas boundary and debt issues.

$13 \quad$ Ibid., 131.

14 Robert Remini, At the Edge of the Precipice: Henry Clay and the Compromise that Saved the Union (New York: Basic Books, 2010). 
According to Remini, "Clay was one of the few men in Congress who understood that any proposal would have to address each one of the several issues raised since the conclusion of the Mexican War." ${ }^{\prime 15}$ Unlike Hamilton, Remini downplayed the roles of President Taylor and Senators John Calhoun and Daniel Webster and ignored the rest of the Senate as well as the House of Representatives during the crisis. He analyzed only Clay's speeches and actions. When the compromise proposal failed to gain Senate approval on July 31, Remini concluded his analysis of the controversy with little discussion of the eventual success of Stephen Douglas who reintroduced the bills in August. Although Remini did not include a bibliography, he cited Congressional debates, correspondence, and other primary sources, as well as Hamilton.

Like Remini, in On the Brink of Civil War: The Compromise of 1850 and How it Changed the Course of American History, John Waugh linked sectional crises to territorial acquisition and slavery. ${ }^{16}$ For the second time in the country's history, the United States gained a large territory, and for the second time a crisis concerning slavery in the territory followed. Waugh described the impasse that occurred during the three years after the United States acquired the Mexican cession and stated that something must be done. President Zachary Taylor believed that what must be done was grant immediate statehood to California as a non-slave state. However, legislative action was impossible until the House of Representatives organized. Waugh described in detail the difficulty of the organizational process in his explanation of the election of Howell Cobb as Speaker of the House. When he moved his discussion to the Senate, Waugh stated that

\footnotetext{
$15 \quad$ Ibid., 67.

16 John C. Waugh, On the Brink of Civil War: The Compromise of 1850 and How it Changed the Course of American History (Wilmington, Del.: Scholarly Resources, Inc., 2003).
} 
the best hope for a solution to the crisis rested with Henry Clay. Waugh presented an indepth examination of Clay's Compromise proposal and the numerous Senatorial arguments against it. In his explanation of the Senate rhetoric, Waugh described in detail the physical appearance of each of the major actors and the impressions each speaker made on others rather than concentrate on the speeches. One of his best descriptions is of a near-duel in the Senate chambers between the "irritatingly present" Henry Foote and "large and heavily framed ... and headstrong" Thomas Hart Benton. ${ }^{17}$ Waugh relied on numerous private letters, diaries, and newspapers as well as the Congressional Globe to recreate the contentious atmosphere. He presented a colorful description of the many personalities involved in the Compromise; however, he ended his discussion at the death of Taylor in early July. He provided a brief summary chapter that stated the Omnibus bill did not pass, and Stephen Douglas later pushed the individual pieces of the bill through the Senate. In the summary, Waugh stated that Northern Democrats and Southern Whigs provided the key to its passage. Despite the book's subtitle, Waugh explained neither the legacy of the Compromise nor how it changed the course of American history.

In the most unique study of the Compromise of 1850 , Craig R. Smith stated that Daniel Webster saved the Union. In The 1850 Compromise: A Study of Freedom of Expression in the United States Senate, Smith compares Webster's Seventh of March speech to his less well known final address in Congress on July 17, 1850 and concluded that Webster achieved consensus in the Senate with the latter address. ${ }^{18}$ Smith's view of Webster's speeches differs from other historians. He believed that Webster's audience for the Seventh of March speech was the Northern public while the audience for the $17 \quad$ Ibid., $125,136$.

18 Craig R. Smith, The 1850 Compromise:A Study of Freedom of Expression in the United States Senate (Washington, D.C.: Freedom of Expression Foundation, 2001). 
farewell address was his fellow Senators. However, Smith does not mention that the Senate defeated the Compromise just two weeks after Webster's second address. Smith's argument that Webster played a more important role in the Compromise could be more persuasive if not for many inaccuracies. He stated that the House of Representatives could not elect a speaker during the balloting in early 1849 (the House held the vote in December), Henry Clay died in 1851 (he died in 1852), and he called Vermont Senator John Hale "John Hate." All of these errors appeared on the first page of the narrative. Smith's complete dismissal of the July 31 rejection of the Compromise bill and his relegation of Clay and Stephen Douglas to the status of on-lookers further reduced the effectiveness of his argument.

For most residents of Indiana, the Fugitive Slave Act was the most controversial piece of the Compromise. In The Slave Catchers: Enforcement of the Fugitive Slave Law, 1850-1860 Stanley Campbell argued that federal officials enforced the law to the best of their ability and further argued that the personal liberty laws enacted by northern states after 1850 did not prevent the return of a single slave to the South. ${ }^{19}$ Campbell discussed the controversy over the constitutionality of the act and the personal liberty laws, the change in northern public opinion toward the act, and both enforcement and non-enforcement of the law. Abolitionists declared the law unconstitutional since courts could not review the decisions of the federal commissioners who determined the status of accused runaways and since the commissioners received fees based on their decisions rather than salaries. Campbell asserted that most northerners accepted the Fugitive Slave Act for multiple reasons until 1854 when the Kansas-Nebraska Act altered public

19 Stanley Campbell, The Slave Catchers: Enforcement of the Fugitive Slave Law, 1850-1860 (Chapel Hill: The University of North Carolina Press, 1968). 
opinion. Despite the shift in public opinion, federal officials still enforced the law with little opposition. In an appendix, Campbell noted 332 federal slave cases between 1850 and 1860. Federal commissioners returned 298 of the 332 to slavery and released only eleven (twenty-two were rescued and one escaped). Exactly one half of the cases, 166, were before Campbell's breakwater year of 1854, with only four of the eleven fugitives returned after that year. This information supported Campbell's claim that the Fugitive Slave Act was enforceable. However, Campbell did not state whether these 332 cases were the only fugitive slave cases. He also failed to mention that thousands of slaves escaped bondage each year and that 332 captures represent a very small number of the escapes. A second appendix noting the number of fugitive slave cases between 1793 and 1850 would be useful in order to determine the necessity of a new Fugitive Slave Act. Despite the omissions, The Slave Catchers added a tremendous amount to the scholarship surrounding the Compromise of 1850 since it is the only monograph to study the Fugitive Slave Act in the 160 years since its enactment.

Campbell's appendix noted a small number of fugitive slave cases in Indiana. In 1921 Charles H. Money wrote a two-part essay titled "The Fugitive Slave Law of 1850 in Indiana" for the Indiana Magazine of History, which every historian who wrote about 1850s blacks in Indiana cited. In part one, Money detailed the role of the Indiana delegation to the Thirty-first United States Congress in the passage of the Fugitive Slave Act. Although neither of Indiana's Senators voted, Money stated that both supported the law. According to Money, Senator Jesse Bright supported the law since he owned slaves in Kentucky, while Senator James Whitcomb supported it only because he believed it would restore harmony to the nation. Money also outlined the positions of Indiana's ten 
members of the House of Representatives. Five of the eight Indiana Democrats and the one Whig voted for the Fugitive Slave Act, while the Free Soil Party member voted against it. After the next election, Democrats controlled nine of the ten seats. Despite the gain, Money concluded the three Democrats who lost reelection did so due to their support of the law. To end part one, Money provided a sample of the support demonstrated by Indiana newspapers for the law and stated that most residents of the state supported it as well. ${ }^{20}$ In part two, Money described both fugitive slave cases and kidnapping trials in the state during the $1850 \mathrm{~s}^{21}$ Although Money cited only the Congressional Globe and state newspapers, he provided case details that he obtained through court records or personal recollections. Money concluded that militant abolitionism grew in the state throughout the decade due to false accusations by slave catchers and the kidnappings. However, he did not mention that hearings officers remanded all but one accused fugitive back into slavery and the only rescue attempt in the state failed. Money provided strong evidence that he did not support the racial discrimination of the 1850s, making it interesting to note that the Indiana Magazine of History published his article over two issues in 1921, a time when the Ku Klux Klan controlled Indiana politics.

In “'The Jordan is a Hard Road to Travel': Hoosier Responses to Fugitive Slave Cases, 1850-1860," a 2003 article in International Social Science Review, Dean Kotlowski analyzed several fugitive cases in Indiana to discern patterns of enforcement. ${ }^{22}$

20 Charles H. Money, "The Fugitive Slave Law of 1850 in Indiana," Indiana Magazine of History 17 (June 1921): 159-198.

$21 \quad$ Charles H. Money, "The Fugitive Slave Law of 1850 in Indiana," Indiana Magazine of History 17 (September 1921): 257-297.

22 Dean Kotlowski, "The Jordan is a Hard Road to Travel," International Social Science Review, 79 (Fall/Winter 2003): 71-88. 
Rather than study every case in the state, Kotlowski chose cases based on their location, the circumstances that surrounded the cases, and the availability of primary sources. $\mathrm{He}$ argued that communities resisted efforts to kidnap free Blacks or prosecute whites for harboring slaves, but provided less support for blacks who were not long-standing residents. Although pockets of resistance existed, Indiana's racist 1851 constitution and lack of personal liberty laws discouraged challenges to the law. Kotlowski believed that judges deferred to slaveholders and residents accepted the decisions. He concluded that support for the Union, racism, and property rights led most residents of Indiana to respect the Fugitive Slave Law. Kotlowski used several state newspapers, but relied more on the major secondary sources, especially David Potter, Stanley Campbell, James McPerson, and Indiana historians Charles Money and Emma Lou Thornbrough.

Although most citizens of Indiana ignored the Fugitive Slave Act by neither aiding runaways nor assisting in their capture, some state residents refused to comply with the law. A small number of residents provided aid to fugitives prior to the act, but after 1850 the reports of illegal assistance to runaways increased. Historians argue whether an organized system of assistance existed and how prominent a role free people played in slave escapes. In one of the earliest accounts of its kind, in 1898 Wilbur Siebert wrote The Underground Railroad from Slavery to Freedom and argued that an organized society that helped slaves escape existed. ${ }^{23}$ Siebert interviewed people who alleged they participated in the organization, and relied on letters, diaries, and other primary sources to piece together independent pieces of evidence from across the northern United States and concluded that multitudes of slaves escaped through the

23 Wilbur Siebert, The Underground Railroad From Slavery to Freedom (New York: Russell \& Russell, 1898). 
network of associates. Based on his research, Siebert created maps of the most often traveled routes through the northern states. He explained the unreliability of census reports since official tables list 1011 slaves who escaped in the entire United States in 1850, yet records of the Philadelphia Vigilance Committee claimed to have aided an average of 1000 fugitives per year from 1830-1860 through that city alone. However, Siebert accepted forty-year old recollections of his sources without question. He also did not explain how fugitives reached the northern states.

Larry Gara repudiated Siebert in several ways. In The Liberty Line: The Legend of the Underground Railroad, Gara argued that an organized society to help slaves escape did not exist. ${ }^{24}$ Rather, scattered groups of men and women who at one time or another gave some type of aide to an escaped slave did occur. Gara further argued that few slaves attempted to escape and love of freedom did not motivate those who did. Many who fled did so to avoid work or punishment or because they had grown tired of their mates. In addition, not all runaways fled to the north or Canada; some stayed in the South, while others hid among the Indian tribes or went to Mexico. The slaves who did runaway depended on their own resources with limited assistance from free Blacks rather than whites. Further, the aide provided by white abolitionists came after the slave entered a free state. Abolitionist folklore maintained the image of a scared, timid fugitive and the key role whites played, but Gara concluded the evidence does not support that myth. However, Southerners accepted and enhanced the myth since they needed to believe slaves were temperamentally incapable of acting without outside assistance. Although the book contained no bibliography, Gara provided extensive footnotes that cited

$24 \quad$ Larry Gara, The Liberty Line: The Legend of the Underground Railroad (Lexington: University of Kentucky Press, 1961). 
abolitionist's memoirs and letters, propaganda writings, and newspapers, as well as Siebert.

Unlike Gara who repudiated Siebert, in History of the Underground Railroad Col. William Cockrum added to Siebert's work. ${ }^{25}$ While Siebert and others contended that most escapes occurred in western Ohio and eastern Indiana, Cockrum alleged that as a teenager in the 1850s he provided assistance to his father and neighbors in aiding thousands of runaways throughout southwestern Indiana, near Evansville. Further, Cockrum provided names and methods of whites who entered Kentucky to entice slaves to runaway. Although Col. Cockrum was a well-respected individual in southwestern Indiana for many years and he undoubtedly participated in slave escapes at some level, he provided no physical evidence to support his claims.

Pamela Peters also supported Siebert. In The Underground Railroad in Floyd County, Indiana, Peters argued that free Blacks provided more support to fugitives in the Floyd County area than earlier reports indicated. ${ }^{26}$ Peters used freedom papers, bills of sale, and deeds of manumission filed in the Floyd County recorder's office to outline the movement of Blacks into the county. However, despite her assertion, Peters detailed the assistance white churches and white residents provided to runaway slaves. Through the use of New Albany and Louisville newspapers as well as oral histories, Peters explained that Floyd County whites knew Presbyterians and Methodists for their condemnation of slavery. Peters contended the Presbyterian New Albany Theological Seminary linked local ministers and church members with an organized effort to aid fugitives. She stated

25 Col. William Cockrum, History of the Underground Railroad (New York: Negro University Press, 1915).

26 Pamela Peters, The Underground Railroad in Floyd County, Indiana (Jefferson, North Carolina: McFarland and Co, Inc., 2001). 
that James Brooks, an elder in the Presbyterian Church and president of the New AlbanySalem Railroad issued free train passes to slaves fleeing north. Peters also found oral traditions within Floyd County's black community that German immigrants aided fugitives.

When the United States government created the Indiana Territory the population was concentrated in the south along the Ohio River and contained a small number of Blacks. Many of the earliest residents and territorial leaders emigrated from slaveholding areas. Historians explain that these early arrivals acted on their Southern-based beliefs and passed laws that limited the rights of Blacks in order to preserve the land for whites, therefore, whites immigrated to Indiana in large numbers. Many historians noted legislative acts that affected Indiana's Black residents after the white immigration, yet few analyzed the motives behind the laws. Only Thornbrough and Trotter offered explanations. Thornbrough explained that Indiana stopped protecting Blacks in order to preserve comity with Kentucky, while Trotter believed the increase in German and Irish immigration led to the increase in racism. However, a more complete evaluation of the motives of Indiana lawmakers could better explain the racial attitudes of Indiana residents. Although historians have given some attention to the status of Black's rights in pre-Civil War Indiana, more scholarship is needed. 


\section{REFERENCES}

\section{$\underline{\text { Government Documents }}$}

Annals of Congress, Proceedings and Debates of the House of Representatives of the United States at the Second Session of the Second Congress, (1792-1793).

The Congressional Globe, First Session, Thirty-first Congress, Volume 21, Part I and Part II, 3 December 1849 - 30 September 1850.

The Congressional Globe, First Session, Thirty-first Congress, Volume 22, Appendix, Part 1, 3 December 1849 - 30 September 1850.

The Congressional Globe, Second Session, Thirty-first Congress, Volume 23, 2 December 1850 - 3 March 1851.

The Congressional Globe First Session, Thirty-second Congress, Volume 25, Appendix, 1 December 1851 - 31 August 1852.

Journal of the Convention of the People of the State of Indiana to Amend the Constitution, Indianapolis: Austin H. Brown, 1851.

Journal of the House of Representatives of the State of Indiana at Their Second Session at Corydon, 1817-1818.

Journal of the House of Representatives of the State of Indiana, 1820-1821, 1830-1831, 1839-1840, 1850-1851.

Journal of the Senate of the State of Indiana at Their First Session at Corydon, 1816.

Journal of the Indiana State Senate, 1831-1832.

Report of the Debates and Proceedings of the Convention for the Revision of the Constitution of the State of Indiana, 1850, Vol. 1, Indianapolis: A.H. Brown, 1850.

The Revised Statutes of the State of Indiana, 1824, 1831, 1843.

The Statutes of the State of Indiana, 1836-1837, 1839-1840, 1840-1841, 1841-1842, 1849-1850. 
The Statutes of the State of Indiana Containing the Revised Statutes of 1852, Vol. 1. $\underline{\text { Judicial Decisions }}$

Baptiste v. State, 5 Blackford, 283-288 (1840).

Donnell v. State 3 Porter 481 (1852).

Graves et al v. State 1, Porter, 368-373 (1849).

Hickland v. State, 8 Blackford, 365-366 (1847).

In re Clark, 1 Blackford, 122 (1821).

In re Susan, 23 Federal Cases, 444-445 (1818).

State v. Cooper, 5 Blackford, 258-259 (1840).

State v. Curzy 19 Kerr, 430 (1862).

State v. Laselle, 1 Blackford, 60 (1820).

$\underline{\text { Newspapers }}$

Louisville Courier. 17 February 1854 - 21 January 1859.

Louisville Journal.

Madison Courier. 4 January 1851 - 5 July 1889.

Madison Tribune.

Madison Weekly Courier. 30 October 1850 - 1 March 1851

New Albany Chronicle.

New Albany Daily Ledger. 3 August 1850 - 14 August 1860.

New Albany Weekly Ledger. 12 November 1850 - 4 December 1850

North Vernon Times.

$\underline{\text { Articles }}$

Barnhart, John. "The Southern Influence in the Formation of Indiana." Indiana Magazine of History 33 (September 1937): 261-276. 
Finkelman, Paul. "Prigg V. Pennslyvania and Northern State Courts: Anti-Slavery Uses of a Pro-Slavery Decision." Civil War History 25 (1979): 5-35.

. "Story Telling on the Supreme Court: Prigg v. Pennsylvania and Justice Joseph Story's Judicial Nationalism.”' Supreme Court Review (1994): 247-294.

Garber, William S. "Jesse D. Bright and Michael C. Garber." Indiana Magazine of History 28 (March 1932): 31-39.

Kotlowski, Dean J. "'The Jordan is a Hard Road to Travel': Hoosier Responses to Fugitive Slave Cases, 1850-1860." International Social Science Review 79 (Fall/Winter, 2003): 71-88.

Money, Charles H. "The Fugitive Slave Law of 1850 in Indiana." Indiana Magazine of History 17 (June 1921): 159-198.

. "The Fugitive Slave Law of 1850 in Indiana." Indiana Magazine of History 17 (September 1921): 257-297.

Shepherd, Randall T. "Slavery Cases in the Indiana Supreme Court: Where Slaves and Former Slaves Found Hope." Traces of Indiana and Midwestern History 15 (Summer, 2003): 34-41.

Thornbrough, Emma Lou. "Indiana and Fugitive Slave Legislation." Indiana Magazine of History 50 (September 1954): 201-228.

\section{$\underline{\text { Primary Sources }}$}

Dow, William S., comp. Negroes in and Around Jefferson County, Indiana. Madison, In.: Jefferson Co. Historical Society, 1950.

Esarey, Logan, ed. Messages and Papers of Jonathan Jennings, Ratliff Boon, and William Hendricks. Vol. 3, 1816-1825. Indianapolis: Indiana Historical Commission, 1924.

Ewbank, Louis B., and Dorothy L. Riker. The Laws of the Indiana Territory, 1809-1816. Indianapolis: Indiana Historical Bureau, 1934.

Philbrick, Francis S., ed. Laws of the Indiana Territory, 1801-1809. Springfield: Illinois State Historical Library, 1930.

Robertson, Nellie Armstrong, and Dorothy Riker, ed. The John Tipton Papers. Vol. 1, 1809-1827, comp. Glen Blackburn. Indianapolis: Indiana Historical Bureau, 1942. 


\section{$\underline{\text { Secondary Sources }}$}

American Anti-Slavery Society. The Fugitive Slave Law and its Victims: Antislavery Tracts No. 18. New York: American Anti-Slavery Society, 1856.

Baker, H. Robert. Prigg v. Pennsylvania: Slavery, the Supreme Court, and the Ambivalent Constitution. Lawrence: The University of Kansas Press, 2012.

Barnhart, John D., and Dorothy L. Riker. Indiana to 1816: The Colonial Period. Indianapolis: Indiana Historical Society, 1971.

Berlin, Ira. Slaves Without Masters: The Free Negro in the Antebellum South. New York: Pantheon Books, 1974.

Bigham, Darrel E. On Jordan's Banks: Emancipation and its Aftermath in the Ohio River Valley. Lexington: The University of Kentucky Press, 2006.

Campbell, Stanley Campbell. The Slave Catchers: Enforcement of the Fugitive Slave Law, 1850-1860. Chapel Hill: The University of North Carolina Press, 1968.

Carmony, Donald. Indiana 1816-1850: The Pioneer Era. Indianapolis: Indiana Historical Society, 1998.

. The Indiana Constitutional Convention of 1850-1851. Indianapolis: The Indiana Supreme Court, 2009.

Cockrum, Col. William M. History of the Underground Railroad. New York: Negro Universities Press, 1915.

Coon, Diane Perrine. Southeastern Indiana's Underground Railroad Routes and Operations: A Project of the State of Indiana Department of Natural Resources, Division of Historic Preservation and Archaeology and the U.S. Department of the Interior, National Park Service. Bloomington: Perinne Enterprises, 2001.

Crenshaw, Gwendolyn J. "Bury Me in a Free Land”: The Abolitionist Movement in Indiana, 1816-1865. Indianapolis: Indiana Historical Bureau, 1993.

Esarey, Logan. A History of Indiana from its Exploration to 1850, Vol. 1. Indianapolis: Hoosier Heritage Press, 1915.

Finkelman, Paul. An Imperfect Union: Slavery, Federalism, and Comity. Chapel Hill: The University of North Carolina Press, 1981. . Slavery and the Law. Madison, Wis.: Madison House Publishers, Inc., 1997. . Slavery in the Courtroom: An Annotated Bibliography of American Cases. 
Washington: Library of Congress, 1985.

Gara, Larry. The Liberty Line: The Legend of the Underground Railroad. Lexington: University of Kentucky Press, 1961.

Griffler, Keith. Front Line of Freedom: African Americans and the Forging of the Underground Railroad in the Ohio Valley. Lexington: The University of Kentucky Press, 2004.

Hamilton, Holman. Prologue to Conflict: The Crisis and Compromise of 1850. Lexington: The University of Kentucky Press, 1964.

Hudson, J. Blaine. Fugitive Slaves and the Underground Railroad in the Kentucky Borderland. Jefferson, North Carolina: McFarland and Co., Inc., 2002.

Kettleborough, Charles. Constitution Making in Indiana, Vol. 1: 1780-1850. Indianapolis: Indiana Historical Bureau, 1971.

Litwack, Leon F. North of Slavery: The Negro in the Free States, 1790-1860. Chicago: The University of Chicago Press, 1961.

Lucas, Marion B. A History of Blacks in Kentucky: Volume 1 From Slavery to Freedom, 1760-1891. Frankfort: The Kentucky Historical Society, 1992.

McPherson, James. Battle Cry of Freedom: The Civil War Era. New York: Ballantine Books, 1988.

Middleton, Stephen. The Black Laws in the Old Northwest: A Documentary History. Westport, Conn.: The Greenwood Press, 1993.

Peters, Pamela. The Underground Railroad in Floyd County, Indiana. Jefferson, North Carolina: McFarland and Co, Inc., 2001.

Potter, David M. The Impending Crisis, 1848-1861. New York: Harper \& Row, 1976.

Remini, Robert. At the Edge of the Precipice: Henry Clay and the Compromise that Saved the Union. New York: Basic Books, 2010.

Siebert, Wilbur H. The Underground Railroad from Slavery to Freedom. New York: Russell \& Russell, 1898.

Smith, Craig R. The 1850 Compromise: A Study of Freedom of Expression in the United States Senate. Washington, D.C.: Freedom of Expression Foundation, 2001.

Stampp, Kenneth. Indiana Politics During the Civil War. Bloomington: Indiana University Press, 1949. 
Taylor, Nikki M. Frontiers of Freedom: Cincinnati's Black Community, 1802-1860. Athens: The Ohio University Press, 2005.

Thornbrough, Emma Lou. Indiana in the Civil War Era, 1850-1880. Indianapolis: Indiana Historical Bureau, 1965.

. The Negro in Indiana: A Study of a Minority. Indianapolis: Indiana Historical Bureau, 1957.

Trotter, Joe William. River Jordan: African American Urban Life in the Ohio Valley. Lexington: University of Kentucky Press, 1998.

Waugh, John C. On the Brink of Civil War: The Compromise of 1850 and How it Changed the Course of American History. Wilmington, Del.: Scholarly Resources, Inc., 2003. 


\section{CURRICULUM VITA}

\begin{tabular}{ll} 
NAME & \multicolumn{1}{c}{ Donald William Var } \\
RESIDENCE & Madison, In. 47250 \\
EDUCATION & $\begin{array}{l}\text { B.A. History } \\
\text { Indiana University } \\
1990\end{array}$ \\
& B.S. Education \\
& Indiana University \\
& 1997
\end{tabular}

PROFESSIONAL Phi Alpha Theta SOCIETIES 